\title{
Last Interglacial paleosols with Argic horizons in Upper Austria and Central Russia - pedogenetic and paleoenvironmental inferences from comparison with the Holocene analogues
}

\author{
Sergey Sedov, Svetlana Sycheva, Victor Targulian, Teresa Pi, Jaime Díaz
}

How to cite:

Sedov, S., Sycheva, S., Targulian, V., Pi, T., Díaz, J. (2013): Last Interglacial paleosols with Argic horizons in Upper Austria and Central Russia - pedogenetic and paleoenvironmental inferences from comparison with the Holocene analogues. - E\&G Quaternary Science Journal, 62 (1): 44-58. DOI: 10.3285/eg.62.1.05

Abstract:

The paleosols of the Last Interglacial are presented in many loess sequences of the European temperate zone by soils with Argic horizon, that are considered to be the pedological response to the bioclimatic conditions of that period. We studied micromorphological, physical/chemical (bulk chemical composition, texture and dithionite-extractable iron) and mineralogical characteristics of two profiles - an Eemian Luvisol in Upper Austria (Oberlaab) and a Mikulino Albeluvisol in Central Russia (Alexandrov Quarry near Kursk) to compare them with recent analogous soils and to make further paleoecological and chronological inferences. Both profiles showed a set of characteristics indicative for weathering of primary minerals, clay transformation illuviation and surface redoximorphic (stagnic) processes. Paleosols demonstrate more advanced development than the Holocene analogues manifested however in different pedogenetic characteristics. The Eemian Luvisol in Upper Austria is characterized by stronger clay illuviation manifested in higher clay content and abundance of illuvial clay pedofeatures in the Bt horizon Mikulino Albeluvisol in Central Russia is more strongly affected by eluvial and stagnic processes evidenced by deeper and more intensive accumulation of bleached silty material and clay depletion. We suppose that the properties of parent materia are responsible for these differences. Russian Albeluvisol is formed on the Dnepr loess poor in weatherable minerals and having limited capacity for buffering acidity and clay formation. The higher development status of the Last Interglacial paleosols compared to the Holocene soils having however same type pedogenesis implies longer soil formation period, that agree with some of the paleobotanical proxies and could include besides MIS 5e part of MIS 5d; the warmer and moister paleoclimate during MIS 5e could also account for more advanced paleosol development Several phases of clay illuviation interrupted by frost structuring and deformation are detected in the Eemian Bt horizon in Upper Austria. It suppose even longer development that could extend to the Early Würmian interstadials (late substages of MIS5)

Letztinterglaziale Paläoböden mit Bt-Horizonten in Oberösterreich und Zentral-Russland: pedogenetische und paläoumweltbezogene Schlussfolgerungen im Vergleich mit den holozänen Analogen

Kurzfassung:

In vielen Löss-Paläoboden-Sequenzen der gemäßigten Breiten Europas ist das letzte Interglazial (dt.: Eem, russ.: Mikulino) durch einen Bt-Horizont (Argic horizon nach WRB) repräsentiert, der als pedologisches Resultat entsprechender bioklimatischer Bedingungen dieser Zeit gedeutet wird. Wir untersuchten mikromorphologische, physikalische/chemische (Gesamtelementzusammensetzung, Korngrößenverteilung und dithionitlösliches Eisen) und mineralogische Charakteristika im Profilabschnitt des EemLuvisols in Oberösterreich (Oberlaab) und des Mikulino-Albeluvisols in Zentralrussland (Alexandrov Grube nahe Kursk). Aus dem Vergleich der Paläoböden mit entsprechenden rezenten Böden ergeben sich paläoökologische und chronologische Schlussfolgerungen. Beide Profile zeigen eine Reihe von Charakteristika, die auf Verwitterung primärer Minerale und Tonminerale sowie Tonverlagerung und redoximorphe Prozesse hinweisen. Die Paläoböden zeigen jeweils eine weiter fortgeschrittene Entwicklung im Vergleich zu entsprechenden holozänen Böden, jedoch anhand unterschiedlicher pedogenetischer Merkmale. Der Eem-Luvisol in Oberösterreich weist ein höheres Maß an Tonverlagerung auf, was durch einen höheren Tongehalt und zahlreiche Toncutane im Bt-Horizont gezeigt wird. Der Mikulino-Albeluvisol in Zentralrussland ist stärker von Auswaschung und Stauwasser betroffen, was sich in tieferer und stärkerer Ansammlung von gebleichtem schluffigem Material und Tonverarmung zeigt. Wir nehmen an, dass das Ausgangsmaterial diese unterschiedliche Entwicklung hervorruft. Der russische Albeluvisol bildete sich auf Dnjepr-Löss welcher im Vergleich zu den Riss-Lössen Oberösterreichs ärmer an leicht verwitterbaren Mineralen ist und daher eine geringere Kapazität Säure zu puffern sowie Ton neu zu bilden aufweist. Das fortgeschrittenere Entwicklungsstadium des letztinterglazialen Bodens im Vergleich zu holozänen Böden, die allgemein demselben Bodentyp entsprechen, spricht für eine längere Bodenentwicklungsphase, was mit paläobotanischen Ergebnissen in Einklang steht. Einerseits könnte der letztinterglaziale Paläoboden neben dem MIS 5e auch Teile des MIS 5d umfassen, andererseits könnte eine intensivere Paläobodenentwicklung durch das wärmere und feuchtere Paläoklima während der Interglazialphase des MIS 5e verursacht werden. Mehrere Phasen der Tonverlagerung, unterbrochen durch frostdynamische Strukturierung und Deformation sind im eemzeitlichen Bt-Horizont in Oberösterreich nachweisbar. Die noch weiter reichende Entwicklung könnte bis in noch jüngere Frühwürm-Interstadiale gereicht haben.

Keywords:

Last Interglacial, paleosol, Argic horizon, paleoclimate

Adresses of authors: S. Sedov*, T. Pi, J. Díaz, Instituto de Geología, UNAM. Circuito de la Investigación Científica, 04510, México DF, Mexico; S Sycheva, V. Targulian, Institute of Geography, RAS. Staromonetny 29, Moscow, 119017. Russia; *corresponding author: sergey@ geologia.unam.mx 


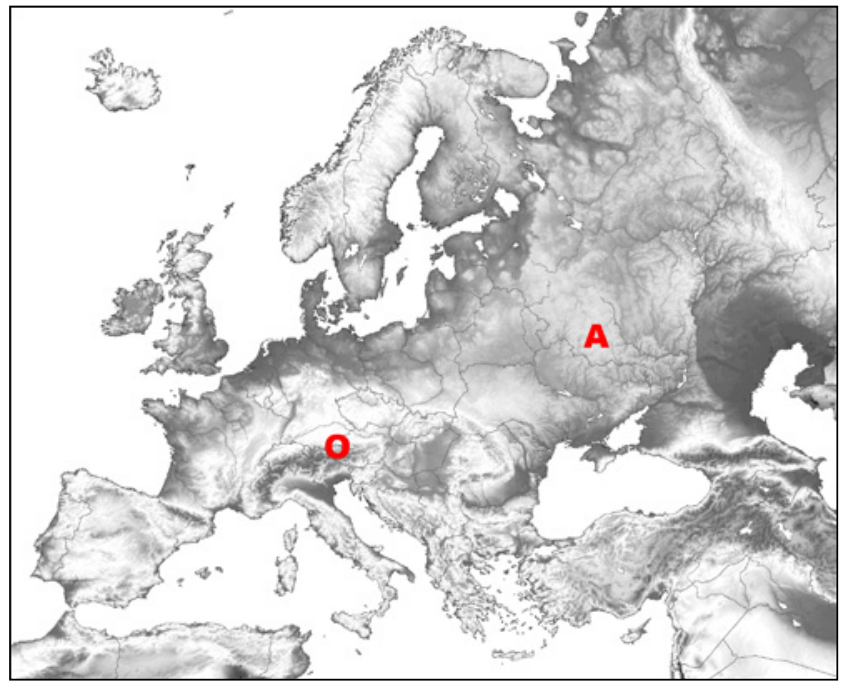

Fig. 1: Geographical situation of the studied profiles. O-Oberlaab, A-Alexandrov.

Abb. 1: Geographische Lage der untersuchten Profile. O-Oberlaab, A-Alexandrov.

\section{Introduction}

The perspective of global climate change increased the interest to the paleoecology of earlier warmer periods, in particular to the Quaternary interglacials. The last interglacial (known in the regional stratigraphies as Riss-Würm, Eemian, Mikulino, Sangamonian) drew special attention as far as the corresponding geological objects and materials are frequent and well preserved. During the last decades a significant progress was achieved in defining the duration of this warm phase and its paleoenvironmental characteristics based on the correlations between marine and terrestrial records (ShackLETon et al. 2003; SiER et al. 2011).

Paleosols of loess-paleosol sequences are among the most important terrestrial records of interglacial environments, especially since these sequences were thoroughly correlated with the deep sea isotope record (KuKLA 1977; BRONGER et al. 1998). In the contemporary temperate zone of Europe the paleosols of the last interglacial are often represented by soil bodies with strong clay illuviation (Haesaerts \& Mestdagh 2000), which were considered to be, with certain limitations, the most significant response of pedogenesis to the interglacial bioclimatic conditions (STEPHAN 2000). The examples are the Ipswichain paleoargillic soils in England (CATT 1996), Rocourt Luvisol in France (ANTOINE et al. 1999) and Belgium (HAEsAerts et al. 1999; VAndenhaute et al. 2003; VANCAMPEnhout et al. 2008), Erbacher Boden - Luvisol/Alfisol/Parabraunerde in Germany (Mahaney et al. 1993; Antoine et al. 2001; TerHORST et al. 2001), lower Luvisol of the PK3 pedocomplex in Czechia (Demek \& Kukla 1969; Frechen et al. 1999) and Nietulisko I - GJ1 pedocomplex in Poland (JARY 2009, 2011), "brown-podzolic soil" of Pryluky-Kaydaky pedocomplex in Ukraine (Rousseau et al. 2001; Gerasimenko 2006) and Salyn paleosol, the Luvisol of Mezin pedocomplex in Central Russia (Velichкo 1990; YAкImenko 1995; Velichкo et al. 2006).

Only in areas with drier continental climate the last interglacial paleosols do not show clay illuviation: in Lower Aus-
tria(Fink 1956; Bronger 1976; PeticzKa 2009; SprafKe et al. 2013 , this volume) it is represented by Cambisols, whereas in the south-eastern part of the East European Plain (RUTTER et al. 2003) and the Carpatian Basin (BRONGER 1976; MARKovic et al. 2008) the last interglacial soils correspond to Chernozems. In fact, in the European temperate zone Luvisols occupied a larger areal in the Eemian soil cover than they do in the Holocene.

This area differs especially in the East European Plain where the zone of forest soils was much broader during the Eemian and occupied a large portion of the present day steppe zone (Morozova 1981; Morozova et al. 1998). In a number of sites in Central Russian and Ukrainian steppe regions one can see a striking difference between Holocene Chernozem on the surface and buried Mikulino Luvisol, separated by Valday loess, all exposed in the same cut (this is also the case in Alexandrov quarry exposure).

In the present day temperate humid forest areas both, last interglacial and Holocene soils show clay illuviation. However, they are often clearly distinguished quantitatively: stronger development of the last interglacial Argic horizons compared to the recent ones was reported in a number of case studies (BOARDMANN 1985; BULlOCK \& THOMPSON 1985; MAHANEy et al. 1993). The reasons for this distinction are not so obvious: differences in bioclimatic conditions as well as in duration of pedogenesis could be involved.

We have to conclude that both paleoecological and chronological aspects of the last interglacial Luvisols development are far from being clear. Concerning the paleoenvironmental setting the assumption that the Bt horizon is a reliable sign of interglacial conditions "defined by the return of the temperate deciduous woods" (STEPHAN 2000) could be too ambitious: we know that in the present day soil cover these horizons occur in a much broader spectrum of ecosystems. In the classic zonal sequence of the Eastern Europe soils with strong clay illuviation are formed on loamy substrates from the broadleaf forests and forest-steppe till boreal coniferous northern taiga (Gerosimova et al. 1996). In fact within the Eurasian forest belt only in the regions with drier extra-continental climate and permafrost in Middle and Eastern Siberia clay illuviation is hampered (Gerosimova et al. 1996).

Broad ecological limits of the recent Argic horizon formation have implications for determining its timing in Europe. In the course of soil evolution during and after Last Late Glacial, clay illuviation is detected not only in the Holocene but also in the late MIS 2 interstadials (KüHN 2003). Some authors attribute the development of Argic horizons in the European Luvisols mostly to the late glacial (BøLLING) boreal paleoenvironment (VAN VLIET LANOË 1990).

Thus the possibility should be considered that also in Mikulino/Eemian paleosols the Luvisol pedogenesis occurred not only during the interglacial sensu stricto but also in transitional phases of colder forest or forest-steppe ecosystems before and after it. In fact, this scenario has been already proposed by various researchers who detected several clay illuviation phases in the Eemian to Early Wurmian pedocomplexes in Belgium (Haesaerts et al. 1999; HAESAERTs \& Mestdagh 2000) and Germany (Antoine et al. 2001; Terhorst et al. 2001). All these authors coincided in discriminating between forest Luvisol development corresponding to the warm humid interglacial and forest-steppe 


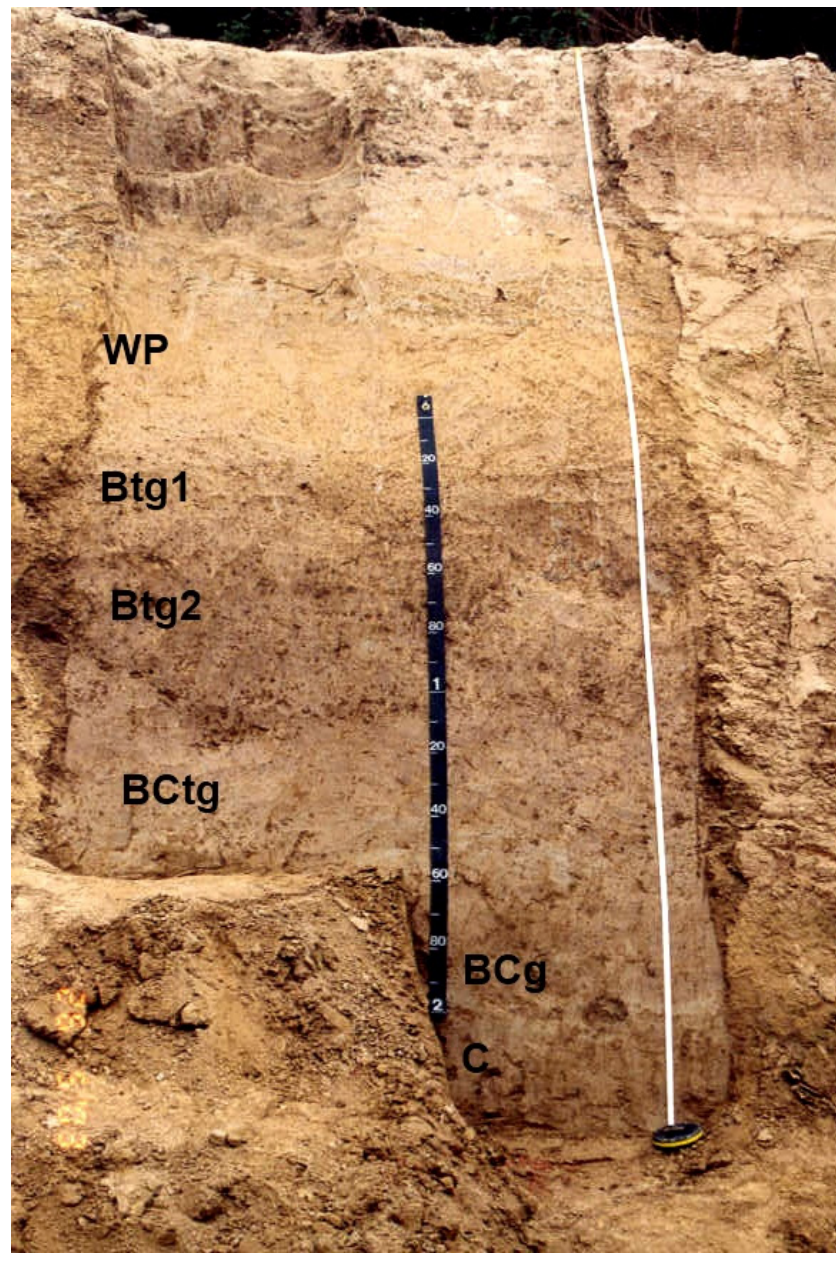

Fig. 2: Profile morphology of the Eemian paleosol of the Oberlaab profile, with the overlying Würmian pedosediment (WP).

Abb. 2: Eemzeitlicher Paläoboden im Profil Oberlaab mit darüber liegendem würmzeitlichem Bodensediment.

Grey Forest Soils attributed to cooler continental climate of the Early Weichselian interstadials. This approach revives the earlier ideas of BOARDMANN (1985) about longer pedogenesis of the Pleistocene interglacial paleosols compared to the Holocene.

However, in most works on loess stratigraphy, chronology and paleoecology the information on paleosol pedogenesis is rather limited: the conclusions are mostly based on field morphological observations, grain size and magnetic susceptibility distribution. Deeper understanding of paleoenvironmental significance of the paleosol of the last interglacial in Europe requires more detailed data about the types and succession of pedogenetic processes - which can be provided by detailed micromorphological and clay mineralogical investigation accompanied by soil chemical analyses (BRONGER 1976; Bronger \& Heinkele 1990; Kemp 1999).

Such detailed study of the buried Luvisols promise to be effective also concerning their comparison with modern surface soils. Temperate forest soils with clay illuviation are provided with one of the most variable and detailed datasets of morphological, physical/chemical and mineralogical characteristics. In fact, these soils were one of the main "experimental polygons" of pedology tor construct scenarios of pedogenesis (including polygenetic models) based on these complex datasets (e.g. TARgUliAN et al. 1974 a,b; KüHN et al. 2006). Thus, the actualistic approach towards paleosol interpretation was expected to be most fruitful in case of the Luvisols.

This research intends to contribute to the knowledge about the last interglacial soil evolution in Europe by carrying out a comparative pedogenetic analysis of two buried paleosols with Argic horizon formed on loess in geographically distant and ecologically dissimilar regions: Upper Austria (Oberlaab section) and Central European Russia (Alexandrov quarry section near Kursk). The final objective is to develop scenarios of paleosol genesis and evolution for both profiles and from this derive conclusions about their paleoenvironmental significance and timing.

\section{Materials and methods}

Two profiles of the last interglacial paleosols from the loesspaleosol sequences were subjected to detailed morphological analysis and sampling being selected as the key sites for the ICSU-2003 project "Polygenetic models for Pleistocene paleosols" (Fig. 1). The profile in Oberlaab (Upper Austria) is located on the fluvioglacial terrace attributed to the Mindel glaciation, close to its bench (TERHORST 2013, this volume). The present day climate is humid providing conditions for broad leaf forest vegetation and for a development of Stagnic Luvisols as dominant modern soil type. The profile Alexandrov quarry (near Kursk, Central Russian Plain) is located at the watershed position close to the slope towards the valley of river Mlodat. The modern climate is temperate semi-humid, the surface soils are Haplic Chernozems formed under meadow-steppe vegetation. Thus, both study sites present two major cases of interrelation between last interglacial Luvisols and the Holocene soil: they belong to the same type in case of Oberlaab and they are genetically dissimilar in case of Alexandrov section.

The stratigraphic, chronological, and paleoecological aspects of both paleosol-sedimentary sequences were published earlier. For Oberlaab these data are available in the papers included in this Special Volume and some earlier publications (Terhorst 2007, 2013, this volume; Solleiro et al. 2013, this volume). The Eemian soil in Oberlaab is the uppermost of 5 buried paleosols; it is separated from the modern soil by colluvial and loessic sediments with signs of weak pedogenesis, attributed to the Würmian glacial. Alexandrov section was studied by Sycheva and co-authors during the last 20 years, the results are presented in several papers (c.f. Sycheva 1998; Golyeva \& Sycheva 2010; Sycheva \& Sedov 2012). Mikulino (Salyn) paleosol is developed on the Dnieper (Rissian Glacial, MIS 6) calcareous loess. The important advantage of Alexandrov section is an extensive and detailed part corresponding to the last (Valday) glaciation, overlying the Mikulino soil. The lower segment of this part is comprised by three Early Valday paleosols clearly separated by colluvial strata. Above them the Middle Valday paleosol is developed (Bryansk soil). Finally, modern Chernozem is separated from Bryansk soil by the Late Valday loess.

Detailed morphological description of the last interglacial paleosol profiles was followed by sampling of the genetic horizons: bulk samples for physical, chemical and mineralogical characteristics and blocks with undisturbed structure for thin sections were collected. Micromorpho- 
logical observations were performed under petrographic microscope and the descriptions followed the terminology of Bullock et al. (1986). We gave special attention to the pedofeatures related to the clay eluvial-illuvial redistribution, redoximorphic processes as well as the signs of aggregation and mixing by biotic and cryogenic processes. The properties selected for paleosol laboratory analyses were those indicative of ancient pedogenetic processes and not subjected to major diagenetic changes after burial. Bulk chemical composition was estimated by X-ray fluorescence analysis. Grain size distribution - intended to estimate clay accumulation due to weathering and illuviation - included separation of sand fractions by sieving and quantification of silt and clay by pipette method. The content of free iron oxides - an important product of soil weathering - was evaluated by measuring Fe in the dithionite-citrate-bicarbonate extract $\left(\mathrm{Fe}_{\mathrm{d}}\right)$. Clay mineral assemblages in the soils with eluvial-illuvial differentiation are known to be specific for different horizons and strongly influenced by pedogenetic processes (TARgulian et al. 1974b; Tonkonogov et al. 1987). We studied the composition of clay fraction by Xray diffraction using a Shimadzu XRD-6000 diffractometer in oriented specimen subjected to different pretreatments: air-dry, saturated with ethylene-glycol, heated to $375^{\circ} \mathrm{C}$ and $500^{\circ} \mathrm{c}$. Clay species content was estimated in semi-quantitatively, using simple peak weighting factors; for area estimation we used Fityk (WoJDYR 2010) program. Illite, smectite and mixed-layered components were identified by separating their peak areas in the glycolated XRD-trace and calculating their proportions (MOORE \& REYNOLDS 1997).

All results were further integrated with other datasets morphological, geochemical, rock magnetic, etc. published for Oberlaab by Solleiro et al. (2013, this volume), for Kursk by Sycheva (1998), Rivas et al. (2003) and Sycheva \& SEdov (2012).

The key element of interpretation consisted in the comparison of obtained results with the existing knowledge about the pedogenetic characteristics of the clay-illuvial soils formed under different environmental conditions: temperate forest of Western and Central Europe (JAMAGNE et al. 1984; KüHN et al 2006; SAUER et al. 2009), taiga (TARGUliAn et al. 1974 a,b; Tonkonogov et al. 1987) and forest-steppe (MIEDEMA et al. 1999) ecosystems of European Russia. Reference profiles for comparison were modern analogues (surface soils) as close as possible to the respective studied profile for which the necessary pedogenetic characteristics were are available: surface Holocene Luvisol for Oberlaab (Solleiro et al. 2013, this volume) and modern Albeluvisol of the Moscow region (TARGULIAN et al. $1974 \mathrm{a}, \mathrm{b}$ ).

\section{Results}

\section{Paleosol morphology from macro- to microscale}

The Eemian soil in Oberlaab is located at a depth of about $3 \mathrm{~m}$ below the Holocene Luvisol, formed on Würmian sediments. The lower part $(60 \mathrm{~cm})$ of the latter directly above Eemian Bt horizon has yellow color, silty loam texture and contains ferruginous concretions. This morphology together with gradual wavy boundary suggests that this layer could be a pedosediment that incorporated material of the Eemian eluvial horizon (indicated in the tables and figures as WP - Würmian pedosediment). The underlying $90 \mathrm{~cm}$ thick brown Btg horizon (subdivided into Btg 1 and Btg2) is darker, more compact and clayey than the overlying pedosediment, with platy/subangular blocky structure. Brown clay coatings cover ped surfaces and fill vertical cracks. Furthermore, few pale coatings of bleached silt, iron concretions and mottles are present. Clay illuvial features decrease in the underlying $\mathrm{BCtg}$ and $\mathrm{BCg}$ horizons (joint thickness about $1 \mathrm{~m}$ ), where larger visible cutans are restricted to very few biogenic pores - channels and chambers. Simultaneously, stagnic colour pattern appears - pale areas, often of subhorizontal lenticular shape are neighboring with yellow mottles of ferruginous pigment. Below follows the pale brown-yellow homogeneous $C$ horizon - the loessic sediment of Riss glaciations separating the Eemian profile from the underlying Middle Pleistocene paleosol (Terhorst 2007; Solleiro et al. 2013, this volume). The soil was classified in the field as Stagnic Cutanic Luvisol (Fig. 2). Under the microscope, the groundmass in all horizons is dominated by coarse silt, having rich and variable mineralogical composition: besides quartz feldspars, amphiboles and micas are abundant. Micas are represented both by colorless muscovite and dark brown biotite; in the latter at stronger magnification signs of weathering are observed - weak interference colors and pleochroism, deformation, precipitation of iron oxides.

The Würmian y0pedosediment (WP) has areas with banded fabric demonstrating stripes of coarse silt and fine material. Frequent ferruginous nodules - rounded, circular, compound are distributed within the groundmass, few thin clay coatings are present. Areas with banded structure were also observed in the Btg1 horizon. Clay illuvial pedofeatures become more abundant in this horizon, being presented both by undisturbed clay coatings (mostly thin and impure) (Fig. 3a) in the pores and fragmented and deformed clusters of illuvial clay incorporated into groundmass. Ferruginous nodules and mottles, mostly with irregular shape and diffuse boundaries are also abundant. Rather big anorthic iron-clay nodules of subangular fragmented shape (Fig. 3b) and charcoal fragments with the tissue structure of a conifer tree were encountered.

The major abundance and variety of clay illuvial materials was found in the Btg2 horizon. Undisturbed clay coatings are present, however, they are not dominant. Fragments of clay illuvial pedofeatures of different size and morphology are more frequent, some of them are larger than any of the undisturbed coatings (Fig. 3c).The Btg2 horizon is characterized by strong fracturing giving rise to angular blocky and coarse lenticular peds (Fig. 3d) and being accompanied by displacement along the cracks. The walls of these cracks support thin undisturbed coatings. Bleached irregular shaped silt concentrations depleted of clay are very rare (Fig. 3e). Few infillings with bow-like structure are of zoogenic origin (Fig. 3f) (KooIsTRA \& PULLEMAN 2010).

Deeper in the BCtg horizon the number of clay illuvial pedofeatures decreases but their preservation increases they are mostly undisturbed coatings in voids, some of them large and laminated (alternating limpid with strong interference colors and impure microlayers) (Fig. 3g,h). Further down the profile in the $\mathrm{BCg}$ horizon clay coatings are even 


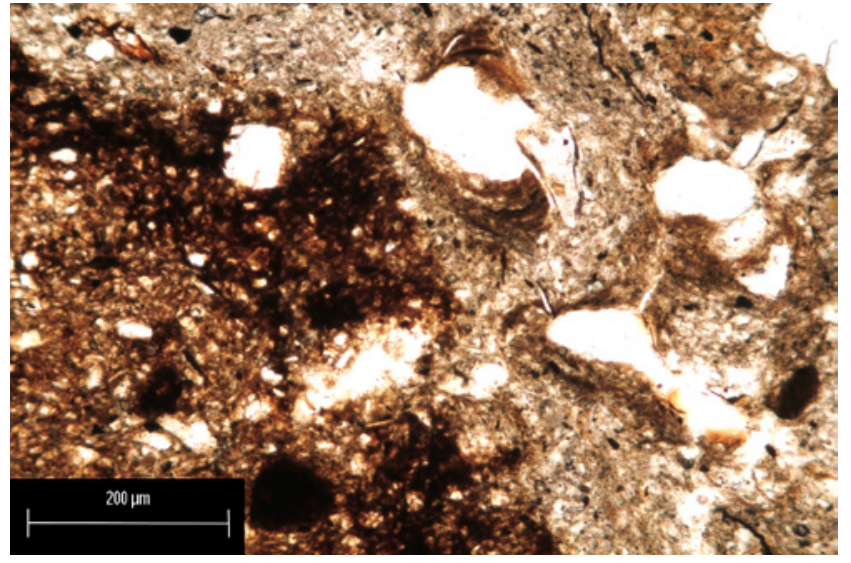

a) Impure clay coatings, Btg1 horizon, plain polarized light.

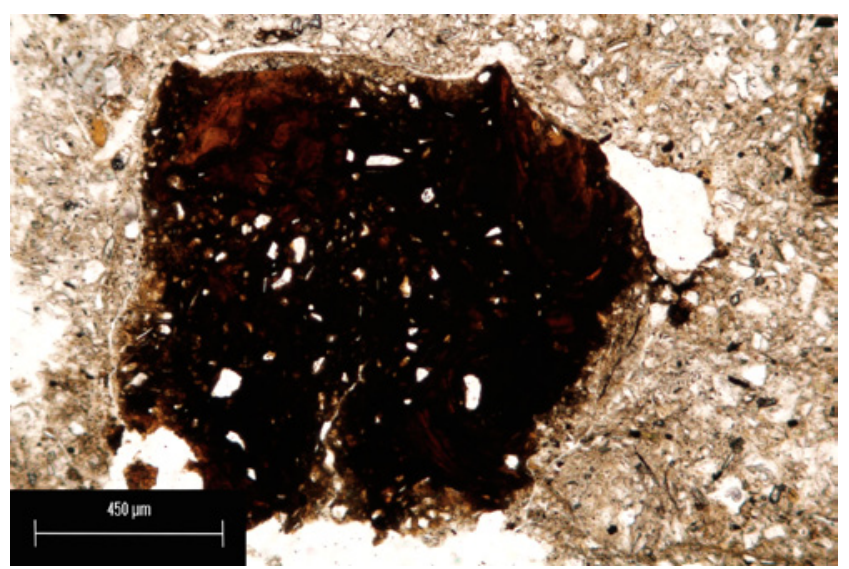

b) Anorthic ferruginous nodule, Btg1 horizon, plain polarized light.

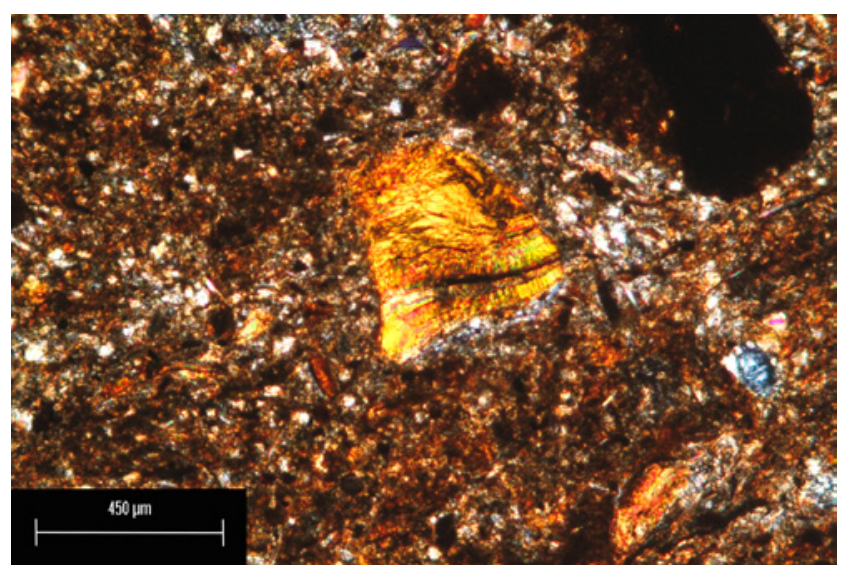

c) Fragment of clay illuvial pedofeature, note strong interference colors and microlamination. Btg2 horizon, crossed polarizers.

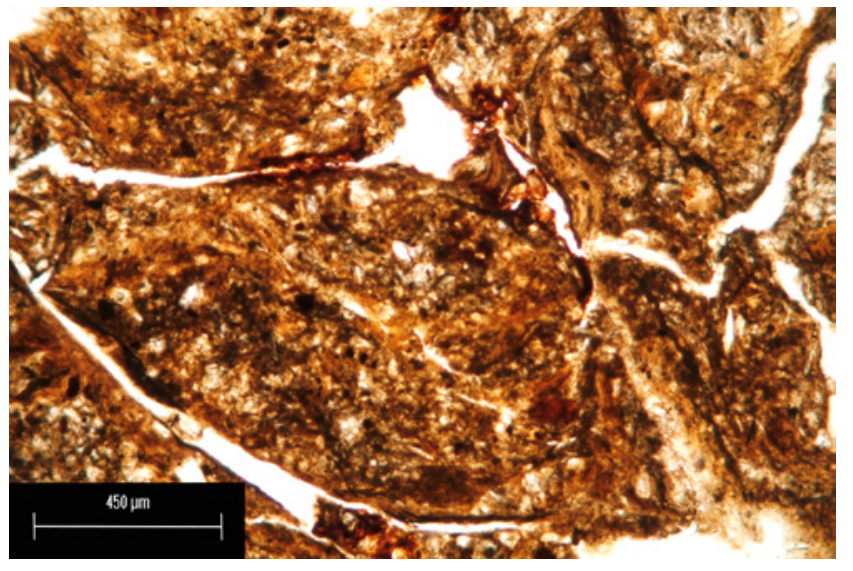

d) Angular blocky - lenticular structure produced by fracturing; note thin clay coatings on the aggregate surface. Btg2 horizon, plain polarized light.

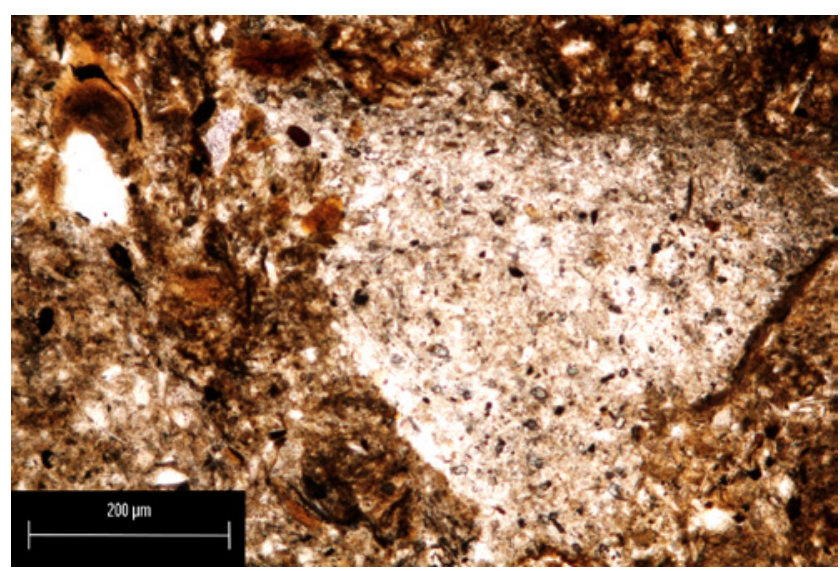

e) Concentration of bleached silt particles. Btg2 horizon, plain polarized light.

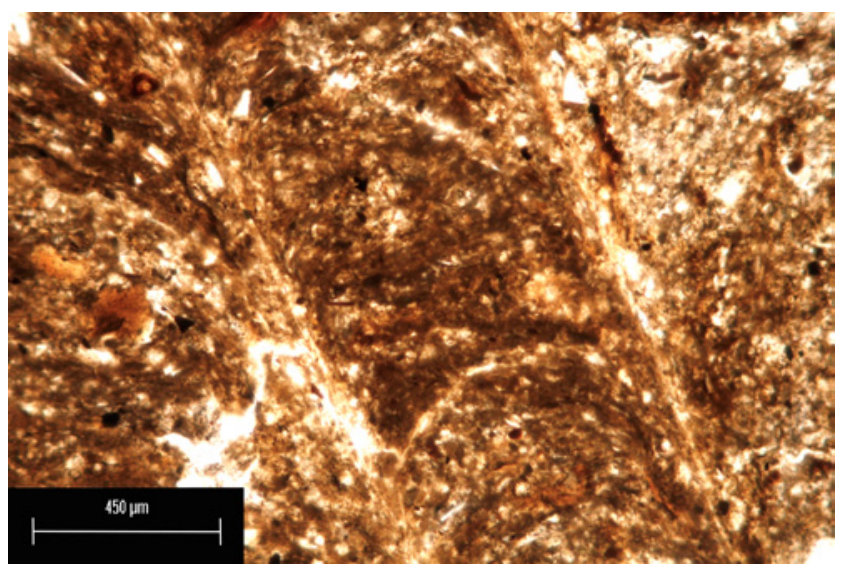

f) Infilling with bow-shaped structure. Btg2 horizon, plain polarized light. 


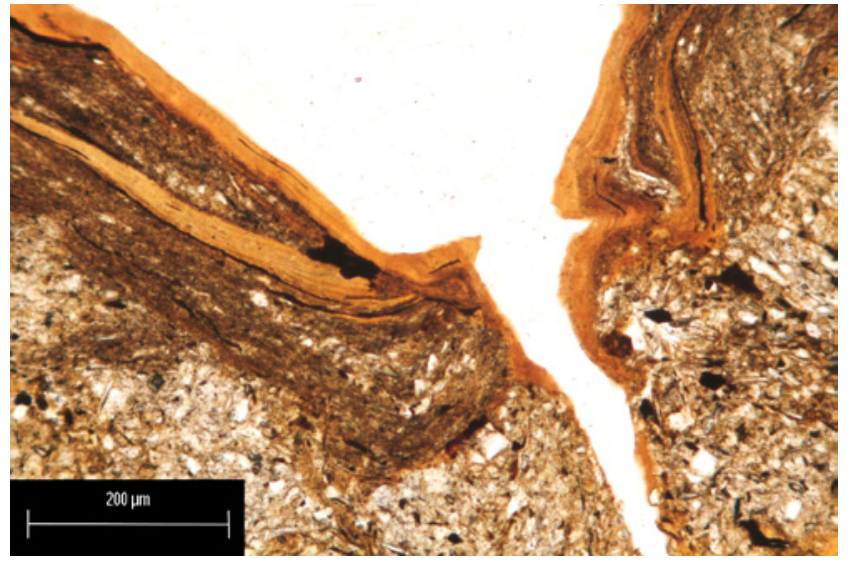

g) Laminated clay coatings with limpid and impure microlayers. BCtg horizon, plain polarized light.

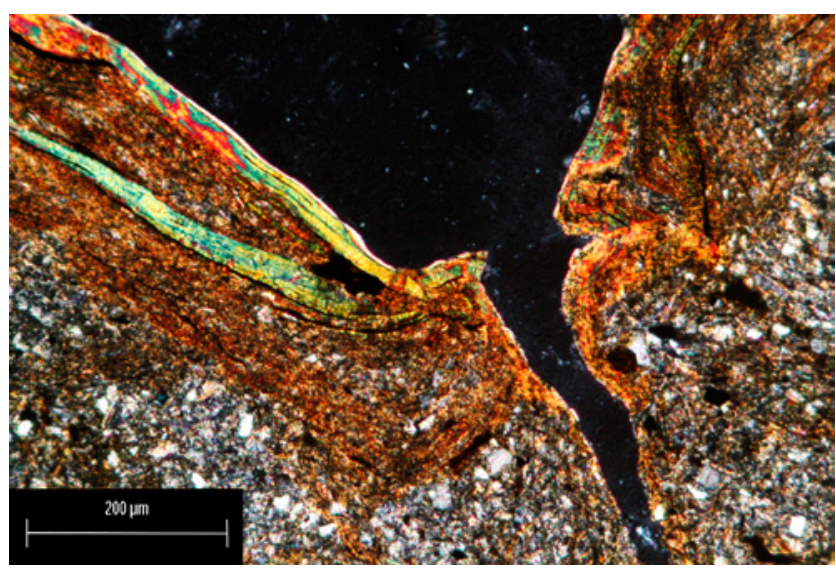

h) Same as g), crossed polarizers; note high birefringence of limpid layers.

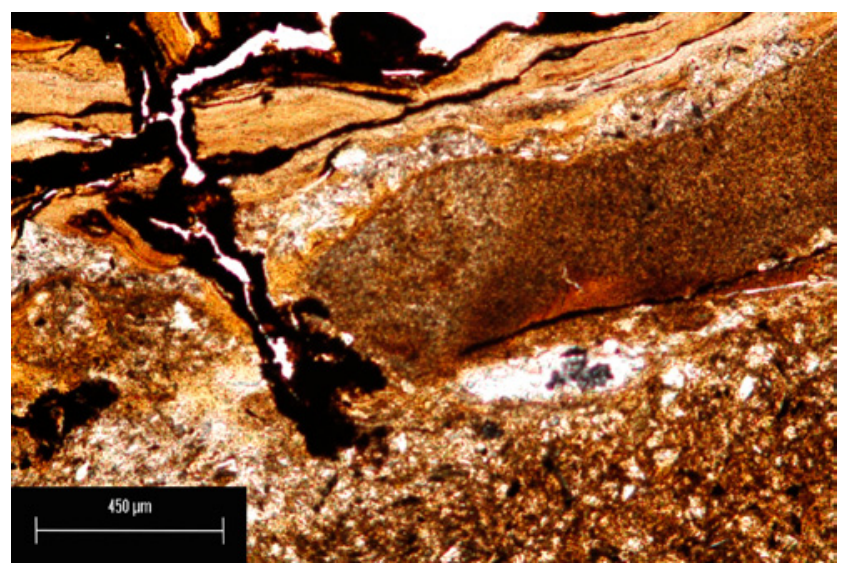

i) Clay illuvial pedofeature with ferruginous coatings on the surface and in the cracks. BCg horizon, plain polarized light.

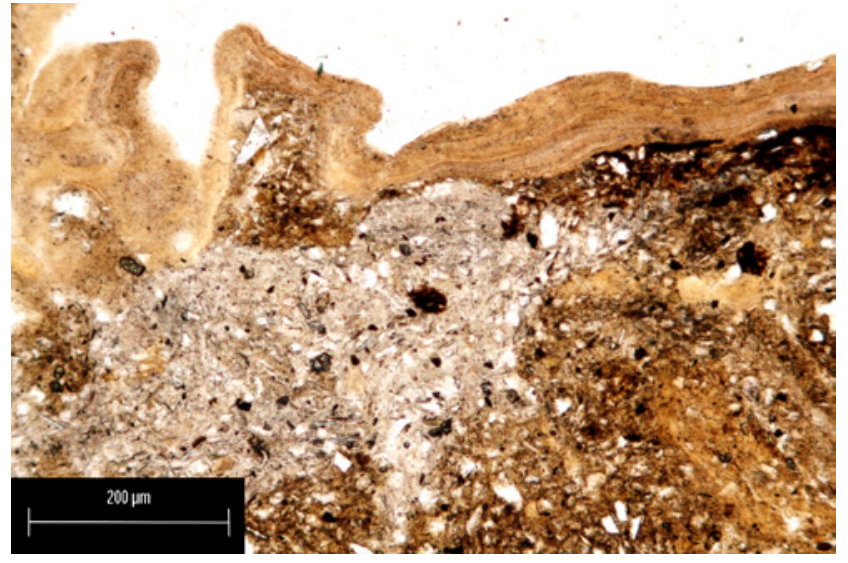

j) Bleached area in the groundmass under clay coating. BCg horizon, plain polarized light.

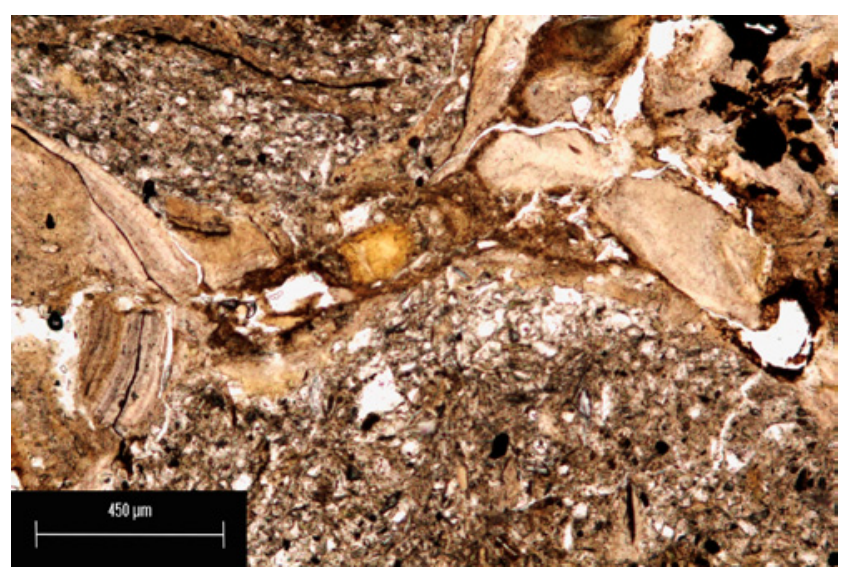

k) Disturbed clay illuvial pedofeature, fragments covered by a thin undisturbed clay coating. $B C \mathrm{~g}$ horizon, plain polarized light.

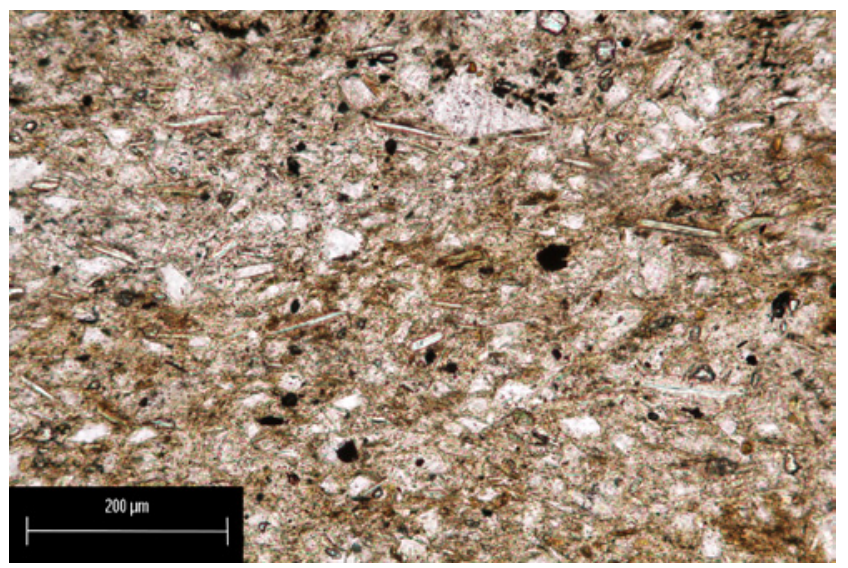

l) Parallel orientation of elongated mineral particles, C horizon, plain polarized light. 


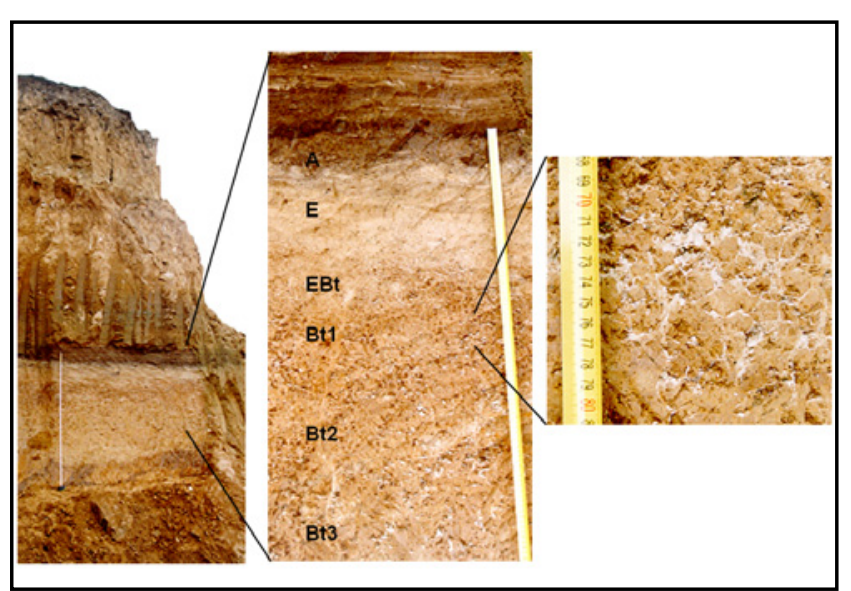

Fig. 4: Profile morphology of the Mikulino paleosol in Alexandrov: position in the sequence, eluvial-illuvial differentiation, detail of the Bt1 morphology, showing bleached areas related to the pores.

Abb. 4: Morphologie des Mikulino Paläobodens in Alexandrov: Lage im Profil, Differenzierung von Eluvial- und Illuvialbereichen, Detailaufnahme Bt1-Horizont mit gebleichten Bereichen, die im Zusammenhang mit Poren stehen.

fewer and usually combined with ferruginous nodules and films penetrating into illuvial clay (Fig. 3i). Frequently, clay coatings in the pores overly bleached microareas adjacent to the pore walls, however, these areas although lacking ferruginous pigment are not depleted of fine clay material (Fig. $3 j$ ). In the $B C$ horizons few clay pedofeatures are fragmented but usually not incorporated into groundmass - the fragments stay in the pores being only slightly displaced and covered by the new generation of thinner cutans (Fig. 3k). Finally in the $\mathrm{C}$ horizon all pedofeatures become less abundant and primary sedimentary structures are more evident - among them parallel subhorizontal orientation of the elongated mineral particles (Fig. 3l)

The profile of Mikulino paleosol as mentioned above is overlain by $6 \mathrm{~m}$ of Walday sediments with a Holocene Chernozem on top. The profile demonstrates a remarkable preservation of all horizons including the topsoil. It is delimited from the overlying laminated colluvial sediments by a thin (less than $1 \mathrm{~cm}$ ) black layer of burned litter. Below it a grey-brown Ah horizon (8 cm thick) is located; it contains numerous charcoal particles (having tendency to parallel orientation) and few soft ferruginous nodules, sometimes associated with the charcoal. It is underlain by the very pale $20 \mathrm{~cm}$ thick E horizon with well-developed multi-order platy structure. Iron oxide nodules (soft and hard) become more abundant, whereas charcoal particles are fewer. An important diagnostic feature is the type of the lower boundary of this horizon. It is gradual with the bleached material penetrating into the underlying layer along pores and fissures and it forms thin glossic fills in the vertical cracks - known as "albeluvic tonguing". The downward "invasion" of bleached silt material defines the $15 \mathrm{~cm}$ thick transitional EB horizon. It still has platy structure, however, platy aggregates are thicker and break into small subangular blocks. The bleached material concentrates on the aggregate surface whereas the internal part is darker and contains more clay. This distribution produces a heterogeneous color pattern: the network of pale veins is spread among the brown "islands". Iron-manganese pedofeatures are presented by small nodules and films mostly associated with the thin fissures.

The illuvial part of the profile (Bt1, $30 \mathrm{~cm}$ thick - Bt2, 35 $\mathrm{cm}$ thick - Bt3, $65 \mathrm{~cm}$ thick) is marked by a contrasting difference of main morphological characteristics. It has clayey loamy texture, subangular blocky to prismatic structure and predominantly brown color. However, silty bleached material is still abundant: in the Bt1 horizon it forms films on most ped surfaces. In many cases these films overly brown clay coatings. In Bt2 the pale silt component decreases and is restricted mostly to the larger vertical cracks. Aggregates are covered with continuous clay coatings. The prismatic blocky peds become coarser and clay coatings on their surfaces turn patchy in the Bt3 horizon. All Argic horizons have also ferruginous pedofeatures, in Bt1 these are mostly small nodules, whereas in $\mathrm{Bt} 2$ and $\mathrm{Bt} 3$ dendritic iron-manganese spots occur.

The $\mathrm{BC}$ horizons have brighter brown-yellow color and weaker pedogenic structure. Where the paleosol lies on Dnieper loess we observed a clear banded pattern in these horizons: darker clayey stripes were alternating with the pale-yellow silty bands.

All these horizons are free of carbonates and the latter appear only in the underlying loess, at the depth of $250 \mathrm{~cm}$ from the Mikulino surface. The paleosol was defined as Haplic Albeluvisol (Fig. 4).

Microscopic observations reveal predominance of silt grains in the groundmass. Their mineralogical composition is rather poor - quartz is clearly dominant, K-Na feldspars are present in minor quantities, micas and heavy minerals are few.

The A horizon has complex microstructure with combination of platy and isometric crumby aggregates. Dark organic pigment with heterogeneous distribution causes interchanging of dark-colored and light-colored micro-zones. There are few signs of faunal activity: some zoogenic channels with excrement infillings were found; groundmass contains numerous charcoal particles (Fig. 5a).

In the E horizon dominant fine platy aggregates demonstrate clear textural differentiation with prevailing bleached coarse silt in the upper parts and close to the pores and fine silt and plasmic material in the central and lower parts. Frequent compact rounded simple iron nodules are widespread in the groundmass, sometimes charcoal is observed in their nucleus (Fig. 5b). We encountered fragments of clay coatings embedded in the bleached silty matrix (Fig. 5c,d).

The EB horizon also has well developed platy structure with even stronger intra-pedal differentiation of particle size. Fine silt and clay is concentrated inside the plates, while the peripherical parts consist of bleached silt. Iron pedofeatures are frequent and variable: we observed rounded nodules and incrustation of platy aggregates mainly on the bottom side (fig. 5e).

Traces of platy aggregation are still observed in the Bt1 horizon but plates are frequently neighbouring subangular blocks (Fig. 5f). The pores have common bleached silty coatings as well as infillings, whereas deformed and fragmented illuviated clay pedofeatures were found in the interior of the peds (Fig. 5g).Undisturbed clay illuvial pedofeatures still related to the pores were not observed. Small ferruginous nodules are found both, in the groundmass and silty infillings. 


\begin{tabular}{|l|l|l|l|l|l|l|l|l|l|}
\hline \multirow{2}{*}{ Horizon } & \multicolumn{6}{|l|}{ Total element concentrations, \% } \\
\cline { 2 - 10 } & $\mathrm{SiO}_{2}$ & $\mathrm{TiO}_{2}$ & $\mathrm{Al}_{2} \mathrm{O}_{3}$ & $\mathrm{Fe}_{2} \mathrm{O}_{3}$ & $\mathrm{MgO}$ & \multicolumn{5}{l|}{$\mathrm{CaO}$} & $\mathrm{Na}_{2} \mathrm{O}$ & $\mathrm{K}_{2} \mathrm{O}$ \\
\hline Eemian paleosol [Oberlaab, Austria] \\
\hline WP upper & 74.14 & 1.12 & 14.86 & 4.95 & 1.03 & 0.81 & 0.97 & 1.94 \\
\hline WP lower & 74.46 & 1.12 & 14.75 & 4.68 & 1.01 & 0.85 & 1.00 & 1.92 \\
\hline Btg1 & 76.16 & 1.03 & 13.15 & 4.66 & 1.09 & 0.66 & 0.94 & 2.11 \\
\hline Btg2 & 70.26 & 0.94 & 16.49 & 6.38 & 1.60 & 0.67 & 0.79 & 2.60 \\
\hline BCtg & 70.58 & 0.95 & 16.02 & 6.30 & 1.63 & 0.81 & 0.88 & 2.58 \\
\hline BCg & 71.37 & 0.94 & 15.33 & 6.01 & 1.59 & 0.91 & 1.04 & 2.56 \\
\hline C & 71.48 & 0.96 & 15.47 & 5.86 & 1.55 & 0.93 & 1.03 & 2.45 \\
\hline Mikulino paleosol & Alexandrov quarry, & $\mathrm{Russia}]$ & & & & \\
\hline A & 82.30 & 0.90 & 9.44 & 2.68 & 0.61 & 0.81 & 0.65 & 2.34 \\
\hline E upper & 85.37 & 0.90 & 7.69 & 1.88 & 0.43 & 0.62 & 0.56 & 2.38 \\
\hline E lower & 83.72 & 0.94 & 8.54 & 2.33 & 0.55 & 0.58 & 0.64 & 2.52 \\
\hline EBt & 81.97 & 0.95 & 9.30 & 3.14 & 0.71 & 0.60 & 0.58 & 2.62 \\
\hline Bt1 & 81.30 & 0.92 & 9.70 & 3.40 & 0.73 & 0.62 & 0.55 & 2.63 \\
\hline Bt2 & 81.01 & 0.81 & 10.23 & 3.44 & 0.78 & 0.64 & 0.53 & 2.37 \\
\hline Bt3 & 80.67 & 0.79 & 10.49 & 3.45 & 0.76 & 0.67 & 0.59 & 2.39 \\
\hline BC & 82.17 & 0.77 & 9.60 & 3.02 & 0.64 & 0.68 & 0.49 & 2.43 \\
\hline
\end{tabular}

Tab. 1: Bulk chemical composition: selected major elements.

Tab. 1: Ergebnisse der Elementaranalysen: Ausgewählte Hauptelemente.

WP - Würmian pedosediment

Only the Bt2 and Bt 3 horizons have undisturbed layered illuvial clay coatings on the pore walls (Fig. 5h). However, bleached silt concentrations are still present and concentrated mainly in fissures and large channels. They have abrupt boundaries to the groundmass, and sometimes they are juxtaposed on the clay coatings or occur in the neighboring pores (Fig. 5i,j).

In the thin sections of the banded $\mathrm{BC}$ horizons we observed a clear laminar structure with alternating bands enriched in coarse silt and fine clay materials. Even in these horizons we observed few thin clay coatings, which showed no clear preference for specific bands.

\section{Physical and chemical characteristics}

Bulk chemical composition demonstrates similar tendencies of profile differentiation in terms of element concentrations. The upper eluvial horizons have higher quantities of Si at the expense of $\mathrm{Al}$ and also $\mathrm{Fe}$ and $\mathrm{Mg}$. However, it should be noted that absolute values are quite different in the two studied profiles: the material of Mikulino paleosol in Alexandrov has much higher Si content $(80-85 \%)$ than that of the Eemian soil in Oberlaab (70-76\%), whereas the latter is more rich in $\mathrm{Al}, \mathrm{Fe}$ as well as alkaline and alkaline earths (except $\mathrm{K}$ that has similar concentrations in both paleosols) (Tab. 1).

Clay content shows a clear and similar distribution trend in both profiles: the maximum is observed in the Bt horizons, whereas lower values are found in the eluvial $\mathrm{E}$ horizon in Alexandrov and upper Würmian pedosediment in Oberlaab (in the latter - with contrasting fluctuations between upper and lower parts). The highest values of the dithionite extractable iron also correspond to the illuvial part of both profiles. However, iron and clay maxima do not coincide: iron content is highest in the upper Bt1 horizons, whereas clay has its maximum below in the Bt2 horizons. Again, both clay and $\mathrm{Fe}_{\mathrm{d}}$ contents although having very similar distribution tendencies in both profiles, demonstrate different absolute values. For both components they are considerably higher in the Oberlaab profile (Tab. 2).

Clay mineral assemblages show very clear differentiation in both studied profiles. Interlayered illite-smectite with variable proportion of both components - (1.4-1.5 nm peak, shifting to smaller angles on glycolation) decreases strongly in the eluvial E horizons and is much higher in the illuvial stratum and parent material. In the Eemian Luvisol of Oberlaab this tendency is rather weak and expressed mostly in different proportions of smectite-rich and smectite-poor mixed layered components. The latter increase in the upper part of the profile. In the Mikulino Albeluvisol of Alexandrov this tendency is much stronger: all smectitic components decrease in the eluvial part, whereas on the contrary, illite and kaolinite (respectively $1.0 \mathrm{~nm}$ and $0.7 \mathrm{~nm}$ peak, the latter disappearing after $550{ }^{\circ} \mathrm{c}$ heating) are more abundant (see Table 3 and Fig. 6). Only in the pedosediments, eluvial and upper illuvial horizons (EB and Bt1) we found mixed-layered minerals with chloritic component ("shoulder" of $1.0 \mathrm{~nm}$ peak towards smaller angles after heating indicating incomplete contraction of 1.4-1.5 nm maximum), which we identify with the hydroxyl-interlayered vermiculite and smectite (HIV and HIS) (BAMHISEL \& BERTSCH 1989).

\section{Discussion}

Pedogenesis of paleosols - comparison with the regional modern analogues

The question to be answered before soil forming processes in the paleosol can be assessed is how complete is their profile 


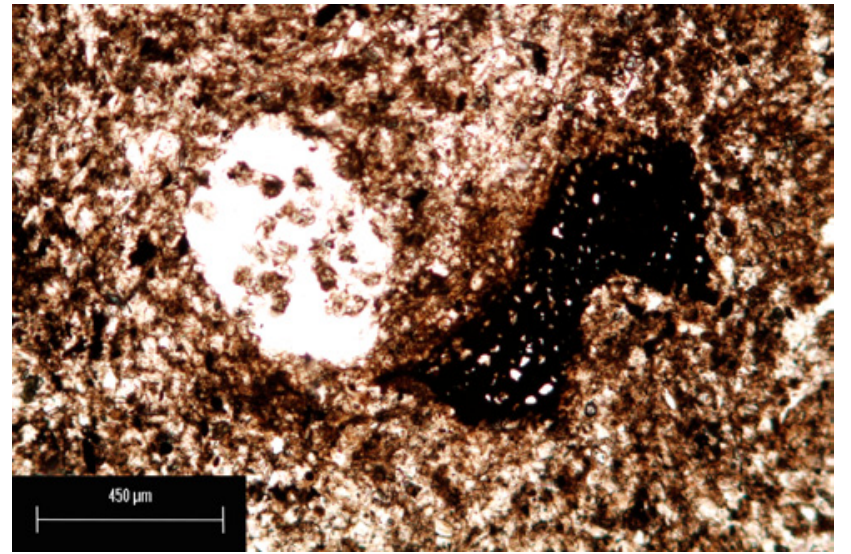

a) Pore with the excremental infilling, charcoal particle. A horizon, plain polarized light.

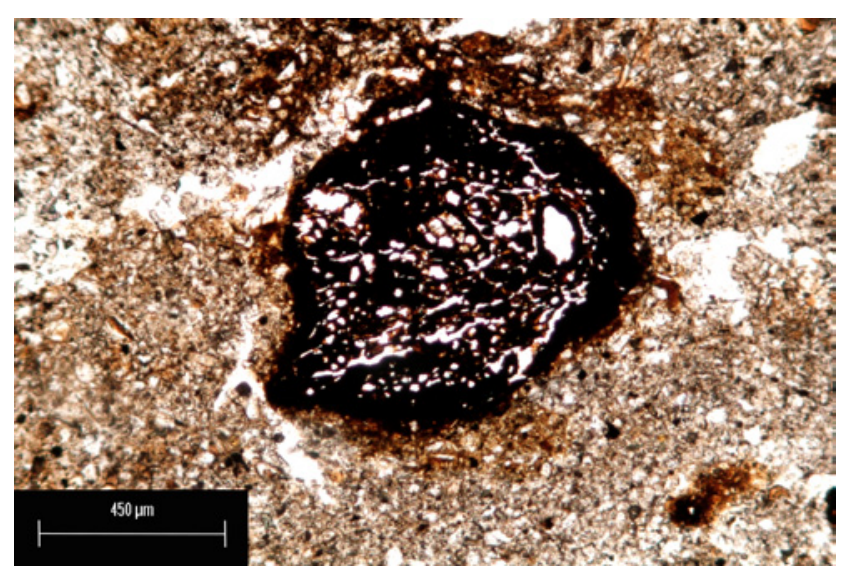

b) Ferruginous nodule with charcoal in the center. E horizon, plain polarized light.

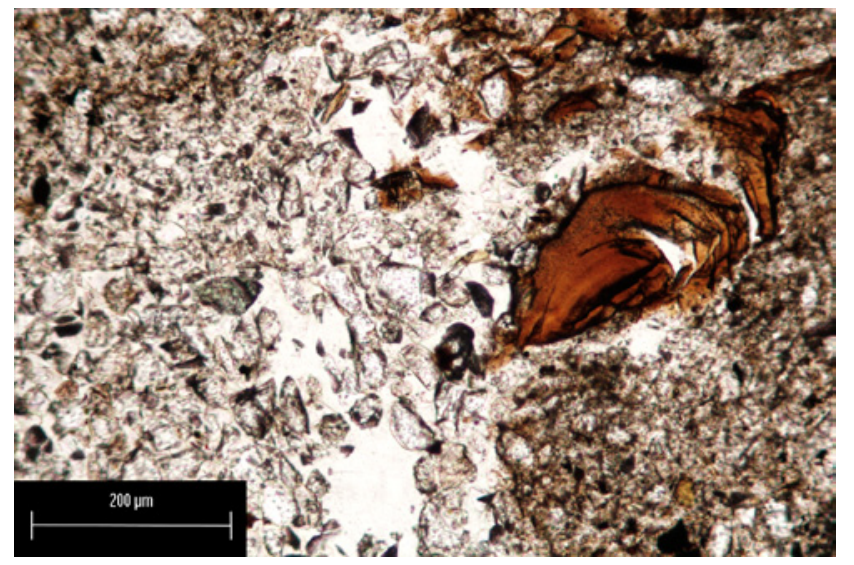

c) Fragment of clay coating surrounded by bleached silt. E horizon, plain polarized light.

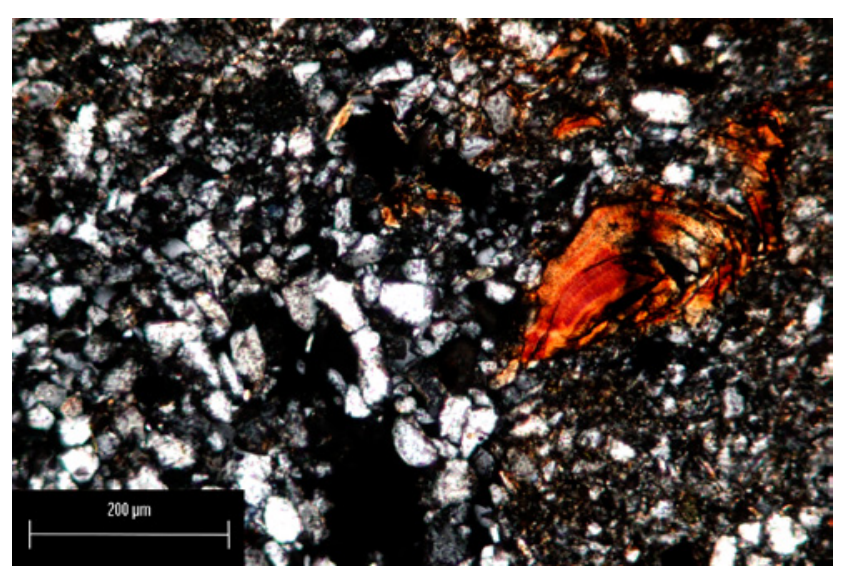

d) Same as c), crossed polarizers; note strong interference colors and undulating pattern of extinction

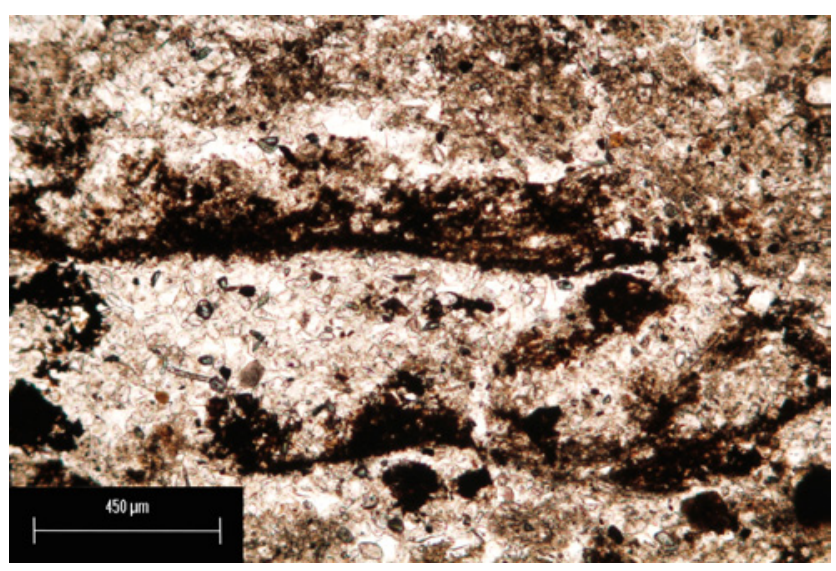

e) Platy structure, fissures between the plates are filled with bleached silt, ferruginous hypocoatings are located on the lower surfaces of the plates. EBt horizon, plain polarized light.

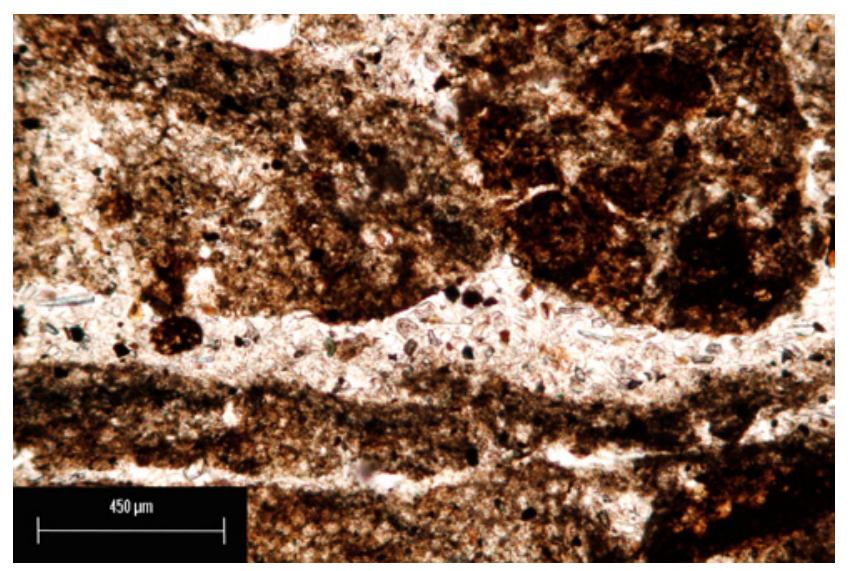

f) Platy and blocky aggregates, pores are filled with bleached silt, intrapedal matrix enriched with fine material. Bt1 horizon, plain polarized light. 


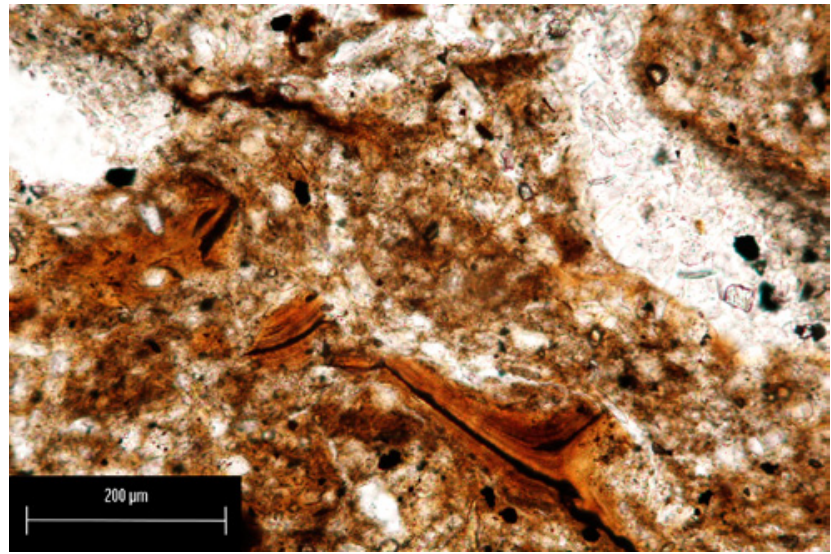

g) Fragmented and deformed clay illuvial pedofeatures incorporated into groundmass. Bt1 horizon, plain polarized light.
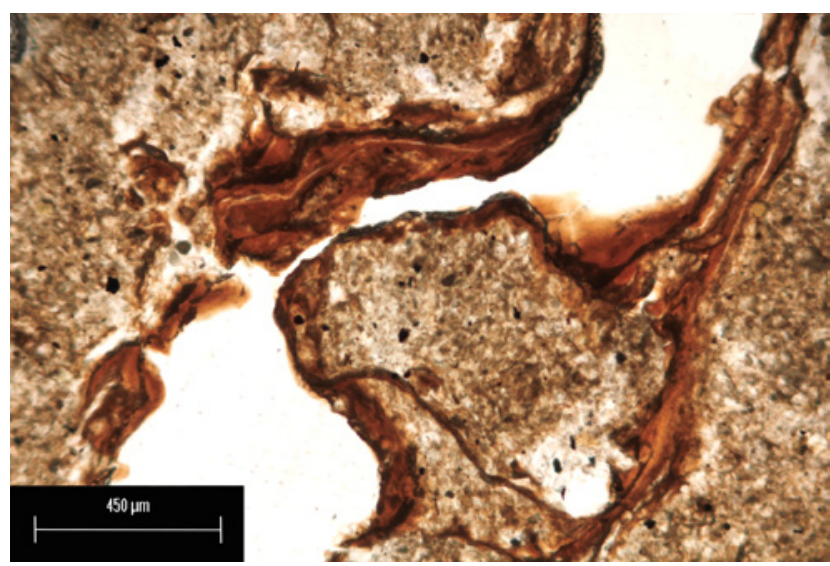

h) Continuous undisturbed clay coating in the pore. Bt3 horizon, plain polarized light.

and to what extend it is affected by post-burial (diagenetic) processes.

In the Oberlaab profile the layer directly above the Eemian Bt horizon has clear signs of sedimentation and mixing. These signs are stronger in the upper part of this horizon, where grain size fluctuations mark a lithological discontinuity; in this layer few thin clay coatings are most probably the lowermost traces of clay illuviation from the Holocene Luvisol. However, stagnic ferruginous pedofeatures and presence of the specific clay component - hydroxyl interlayered vermiculites and smectites suggest that material of the eluvial horizon, although redeposited is present in this layer. Minor signs of disturbance (anorthic iron-clay nodules, charcoal) are present even in the Bt1 horizon, and the paleosol is supposed to be intact only below the Bt1 (Terhorst et al. 2003).

In case of Alexandrov quarry the grade of preservation is high: a complete sequence of genetic horizons including the burned litter is present. Only the A horizon has signs of redeposition: oriented charcoal particles. Moreover, no effects of posterior pedogenesis are detected in this paleosol, due to its protection by a thick overlying sediment layer.

In both profiles a similar set of pedogenetic processes is detected. Clay illuviation is evidenced by clay coatings (observed both on macro- and microscale) as well as a maximum of clay content in the Bt horizon compared both to the underlying $\mathrm{C}$ and overlying $\mathrm{E}$ horizon (in situ or redepos-

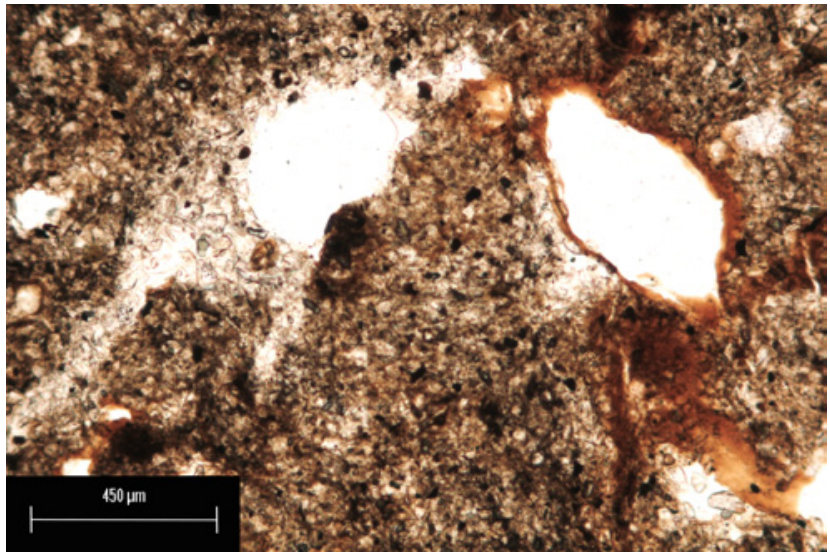

i) Bleached silt (left) and limpid clay coating (right) in the neighboring pores. Bt3 horizon, plain polarized light.

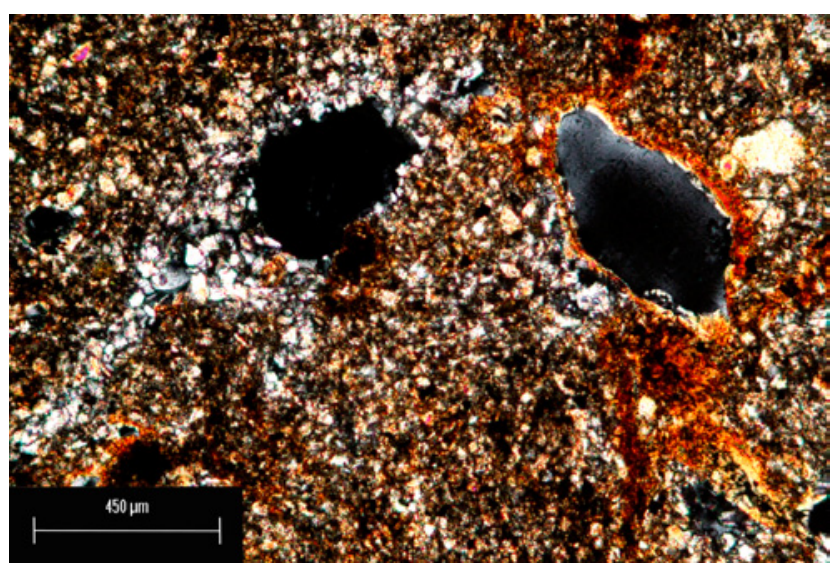

j) Same as i), crossed polarizers, note strong interference colors of the clay coating.

ited). Clear micromorphological signs of silicate weathering are observed in the biotite particles. Increase of dithionite extractable iron, which mostly includes fine oxides produced by weathering is an important analytical indicator. An enhanced Si content in the eluvial horizons of Luvisols is often interpreted as a result of decay of all unstable silicates (including part of clay minerals) and residual accumulation of quartz (TARGULIAN et al. 1974b). Loss of smectites in the same horizons is also considered to be a result of selective destruction of the most unstable clay components (ToNKONOGOV et al. 1987). However, it should be taken into account that clay illuviation could also contribute to these properties. Removal of clay from $\mathrm{E}$ horizon also could cause an increase of $\mathrm{Si}$, due to relative accumulation of coarse components richer in this element. Smectites are most fine and dispersable components, that could be preferentially mobilized by suspension transport and removed from the eluvial horizons (VAN RANST et al. 1982). Thus, geochemical and mineralogical indicators give a mixed signal from both processes, a fact that unfortunately is rarely taken into account when elemental composition of loess-paleosol sequences is interpreted through various "weathering indices".

More clear evidence of clay mineral transformation is provided by the HIV accumulation in the upper part of the paleosols. This component is known to be formed from 2:1 clay minerals with labile structure due to synthesis of 
Tab. 2: Grain size distribution and dithionite extractable iron content. Tab. 2: Korngrößenzusammensetzung und dithionitlöslicher Eisengehalt.

\begin{tabular}{|l|l|l|l|l|}
\hline \multirow{2}{*}{ Horizon } & \multicolumn{3}{|l|}{ Grain size fractions, \% } & \multirow{2}{*}{ Fe $_{\mathrm{d}} \%$} \\
\cline { 2 - 4 } \multicolumn{2}{|l|}{ sand } & \multicolumn{2}{l}{ silt } & \multicolumn{2}{l}{ clay } & \\
\hline Eemian paleosol [Oberlaab, Austria] \\
\hline WP upper & 5.4 & 68.5 & 26.1 & 0.69 \\
\hline WP lower & 8.2 & 69.8 & 22.0 & 0.65 \\
\hline Btg1 & 10.1 & 66.7 & 23.2 & 0.98 \\
\hline Btg2 & 6.3 & 55.9 & 37.8 & 0.73 \\
\hline BCtg & 4.6 & 60.9 & 34.5 & 0.61 \\
\hline BCg & 4.3 & 64.4 & 31.3 & 0.37 \\
\hline C & 5.7 & 65.4 & 28.9 & 0.50 \\
\hline Mikulino paleosol [Alexandrov quarry, Russia] & \\
\hline A & 1.4 & 81.8 & 16.8 & 0.49 \\
\hline E upper & 1.4 & 88.7 & 9.9 & 0.22 \\
\hline E lower & 1.2 & 86.5 & 12.3 & 0.32 \\
\hline EBt & 1.1 & 79.3 & 19.6 & 0.43 \\
\hline Bt1 & 1.0 & 78.2 & 20.8 & 0.51 \\
\hline Bt2 & 1.2 & 70.3 & 28.5 & 0.45 \\
\hline Bt3 & 1.5 & 76.1 & 22.4 & 0.43 \\
\hline BC & 1.2 & 80.0 & 18.8 & 0.37 \\
\hline
\end{tabular}

WP - Würmian pedosediment

fragmentary Al-hydroxyl layer between the 2:1 stacks. This process takes place in acid soil environment and $\mathrm{Al}$ for it is provided by hydrolytic alteration of silicates - primary, or the same clay components (BAMHISEL \& BERTSCH 1989). Presence of these components in the eluvial horizons (in situ in Alexandrov and redeposited in Oberlaab) point to acid weathering in both interglacial paleosols. However, the alternative explanation of higher content of chloritic component in the upper horizons of acid forest soils on loess also exists. JAMAGNE et al. (1984) suppose that these minerals are not formed through the synthesis, but rather by simple breakdown and partial degradation of primary chlorites from silt fractions.

Surface redoximorphic (stagnic) processes produced ferruginous pedofeatures throughout the profile, but most abundant and variable in the eluvial and upper Bt horizons. There they are presented by nodules as well as by coatings and incrustations, indicative of iron migration (BRONNIKovA et al. 2000). Besides intra-horizontal short-distance redistribution we suppose certain eluvial-illuvial transport of iron from $\mathrm{E}$ to $\mathrm{EB}$ and upper Bt horizons due to this process. Dithionite extractable iron is depleted in $\mathrm{E}$ horizons and has its maximum in the Bt1; also the abundance of the ferruginous pedofeatures is maximal in the $\mathrm{EB}$ and $\mathrm{Bt} 1$ horizons. Interestingly magnetic susceptibility also demonstrates maxima in EB (Alexandrov quarry) (RIvAs et al. 2003) and Bt1 (Oberlaab) (Solleiro et al. 2013, this volume) that could also be related to the increase of pedogenic iron oxides. It should be taken into account that surface redoximorphic processes could also contribute to acid weathering and HIV neoformation through the process of ferrolysis (BRINKMAN 1970).
Being similar regarding the set of the pedogenetic processes the studied paleosols differ greatly in their relative development. The Austrian paleosol demonstrates much stronger clay illuviation in the Bt horizon, whereas the Russian profile has much stronger evidences of eluvial and surface redoximorphic processes. This tendency becomes even clearer by comparison with the modern soils. The Eemian soil in Oberlaab has higher clay content and more abundant clay illuvial pedofeatures than the overlying Holocene Luvisol (Solleiro et al. 2013, this volume). The Mikulino Albeluvisol in Alexandrov quarry compared to the local Holocene soil, a Haplic Chernozem, shows contrasting qualitative differences in the set of key pedogenetic processes. The Chernozem is characterized by high accumulation of dark humus and development of coprogenic granular structure resulting in the development of Mollic topsoil horizon. Below, in the Bk horizon abundant neoformed carbonates are observed. Morphological features of clay translocation are very few (if any), clay content is rather uniform throughout the profile showing no tendency towards eluvial-illuvial differentiation (GERAsimova et al. 1996; Bronger 2003). This set of pedogenetis properties typical for steppe pedogenesis under Ustic soil moisture regime (BRONGER 2003) provides undoubted evidence that on the local scale the Holocene climate has been drier than that of the last interglacial - in agreement with the above mentioned reconstruction for Eastern Europe by Morozova (Morozova 1981; Morozova et al. 1998). For current research it is interesting to compare the studied Mikulino profile with the nearest analogue having similar profile organization, to assess changes in the Albeluvisol pedogenesis on the regional scale. The Mikulino Albeluvisol in Alexandrov quarry compared to the Holocene Albeluvisol of the Moscow region (TARGULIAN et al. 1974b), does not show stronger clay accumulation,which is contrary to the case study in Low Austria. However, it demonstrates major advance of eluvial and stagnic processes - bleaching and clay depletion besides E and EB horizons affected the whole Bt horizon, "attacking" the area of earlier clay illuviation. Fresh illuvial pedofeatures pointing to active clay illuviation appear only in the lower Bt2 and BtC horizons. In profiles of Holocene Albeluvisols (KüHN et al. 2006) and Grey Forest Soils (Miedema et al. 1999) this "aggression" of eluviation against degrading illuvial areas is also observed but usually is not so deep. It is strong in EBt horizon and decreases in the upper part of Bt horizons, where it is represented mostly by deep thin bleached tongues (albeluvic tonguing), whereas the areas between the tongues are much less affected (SPIRIDONOva et al. 1999; SAUER et al. 2009). Thus, in both cases last interglacial paleosols present higher grade of development than analogous Holocene profiles in the region, however, the particular mode of this tendency is different.

These differences could be explained when linked to the classic evolution scheme for forest soil formation under temperate humid climate (PÉDRo et al. 1978). Following this scheme intensive clay illuviation develops after initial leaching phase and results in the formation of Argic horizon. However, it is succeeded by the subsequent "degradation" stage of further acidification, surface redoximorphic processes and (possibly) ferrolysis. At this stage clay illuviation is hampered and part of accumulated clay is lost due to acid weathering. We suppose that Eemian Luvisol in Oberlaab 


\begin{tabular}{|c|c|c|c|c|c|}
\hline \multirow[t]{2}{*}{ Horizons } & \multicolumn{5}{|c|}{ Types of clay minerals } \\
\hline & Smectite/ illite & $\begin{array}{l}\text { Illite / } \\
\text { smectite }\end{array}$ & $\begin{array}{l}\text { Chloritised 2:1 } \\
\text { minerals }\end{array}$ & Illite & Kaolinite \\
\hline \multicolumn{6}{|c|}{ Eemian paleosol [Oberlaab, Austria] } \\
\hline WP upper & - & $x x x$ & $x$ & $x x x$ & $x x$ \\
\hline WP lower & - & $x x x x$ & $x x$ & $x$ & $x$ \\
\hline Btg 1 & - & $x x x x$ & $x x$ & $x$ & $x$ \\
\hline BCtg & $x X X X$ & $x x$ & - & $x$ & $x$ \\
\hline $\mathrm{BCg}$ & $x x x x x$ & $x$ & - & $x x$ & $x$ \\
\hline C & $x x x x x$ & $x$ & - & $x x$ & $x$ \\
\hline \multicolumn{6}{|c|}{ Mikulino paleosol [Alexandrov quarry, Russia] } \\
\hline E upper & - & $x x x$ & $x x$ & $x$ & $x x$ \\
\hline E lower & - & $x x$ & $x x$ & $x x$ & $x x x$ \\
\hline EBt & - & $x x$ & $x x$ & $x x$ & $x x$ \\
\hline Bt2 & $X X X X$ & $x x$ & - & $x$ & $x$ \\
\hline C & $x x x x x$ & - & - & $x$ & $x$ \\
\hline
\end{tabular}

Tab. 3: Clay mineral composition.

Tab. 3: Tonmineralogische Zusammensetzung. still developed within the stage of predominant clay formation and illuviation, whereas Mikulino Albeluvisol in Alexandrov quarry already reached the stage of "degradation".

This difference in the evolutionary status is most probably related to the composition of the paleosol parent material. The Riss loess in Austria is richer in weatherable minerals (including phyllosilicates like biotite), has more clayey texture, is enriched in bases and has lower Si content. This increases the potential for neutralizing excessive acidity as well as for the neoformation of clay and iron oxides. The Dnieper loess in much poorer, strongly enriched in quartz, thus buffering and clay generating capacities are lower.

\section{Chronological and paleoecological background of the advanced Eemian/Mikulino paleosol development}

On the local scale, especially in the border regions, qualitative differences between Mikulino/Eemian paleosol and modern soil profile are clearly related to climatic shift as shown by the case of Alexandrov exposure. The question arises, what are the reasons why last interglacial paleosols demonstrate more advanced development than Holocene soils belonging, however, to the same type of pedogenesis (proven by similarity of horizonation, main macro- and micromorphological characteristics, clay mineral association etc.)? We suppose that in many cases the duration of pedogenesis rather than "strong interglacial paleoclimates relative to the present-day climate" (as supposed by MAHANEY et al. 1993) could account for these differences. Comparison with the European paleobotanical records with high-resolution chronological scale provides insight into this problem. Detailed correlation with the deep sea isotope records and establishing the precise position of Blake paleomagnetic event allowed reliable dating of the main paleobotanic phases of Eemian established earlier in the pollen spectra from terrestrial (mostly lacustrine) sediments (ZAGWIJN 1996; TURNER 2002a). Earlier the last interglacial was associated with the Marine Isotope Stage (MIS) 5e (ShakLETon 1969). Recently, it was shown that the spread of forest vegetation in Europe postdated the onset of MIS 5e but on the other hand extended into the subsequent stage $5 \mathrm{~d}$ despite the beginning of global cooling, increase of ice volume, and drop of sea level (SHAKLETON et al. 2003; SIER et al. 2011). This extension concerns in particular the last "post-temperate" paleobotanical phase of boreal forests. Thus, although the duration of the last interglacial sensu stricto is supposed by many authors to be about $11000 \mathrm{yr}$ (similar to that of the Holocene) (CASPPERS et al. 2002; TURNER 2002b), the total succession of the Eemian forest vegetation phases in the Western and Central Europe could reach $20,000 \mathrm{yr}$ - nearly twice longer than the Holocene (KuKLA et al. 2002).

It should be stressed that all phases of humid forest ecosystems including the last one of the boreal forests provide conditions for clay illuviation and development of Argic horizons on loess-like sediments. Thus, the scenario of longterm clay illuviation during the complete succession of different forest phases during MIS5 explains more advanced development of Eemian/Mikulino paleosols compared to the Holocene analogues. Rather cold climatic conditions during the last stages of Albeluvisol profile development in Central Russia are confirmed by micromorphological observations. Typical features of eluvial-illuvial processes are combined with deep frost effects in the upper part of the profile. Lenticular structure with the microscale grain size differentiation is related to ice lensing (VAN VLIET-LANOË 2010), iron incrustations of the platy aggregates are also characteristic for seasonally deeply frozen soils (FEDOROva or YARILOVA 1972).

An even more complex scenario for interaction of illuvial and frost processes is required for the Eemian Luvisol in Oberlaab. Here, the illuvial and frost features not only coexist but show complex interaction. Frost fracturing propagates into the Bt horizon disrupting the older generation of the clay illuvial pedofeatures and generating blocky-lenticular structure, whereas the younger generation of clay coatings covers these aggregates. The clay translocation process itself was heterogeneous as evidenced by variable composition of illuvial pedofeatures. Impure dusty and coarse clay coatings ("mud cutans") are attributed to the 

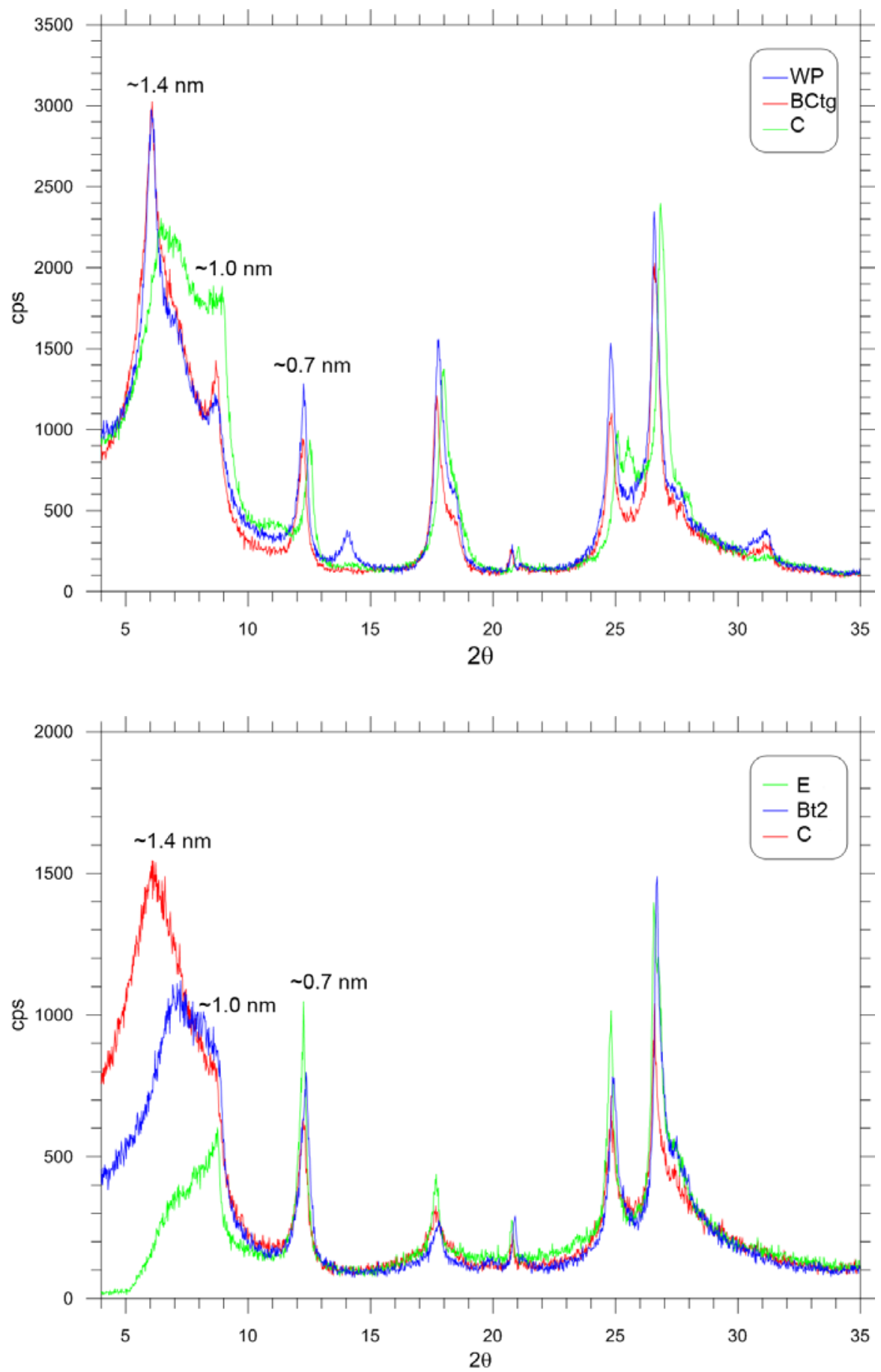

Fig. 6: X-ray diffraction patterns of oriented air-dry specimens of clay fractions from selected paleosol horizons; a) Oberlaab profile, $b$ ) Alexandrov profile.

Abb. 6: Röntgenbeugungsdiagramme von orientierten luftgetrockneten Proben der Tonfraktion aus ausgewählten Horizonten der Paläoböden; a) Profil Oberlaab, b) Profil Alexandrov.

fast percolation of suspensions after snowmelt in freezethaw soils (VAN VLIET-LANOË 2010). The laminated clay coatings (which we observed in the lower part of the Eemian Luvisol of Oberlaab) where pure limpid and impure silty microlayers are juxtaposed, could be interpreted as alternation of "normal" illuviation due to slow percolation and fast deposition from snow melt suspensions (KüHN et al. 2010).

This suggests that clay illuviation in the Oberlaab profile was polygenetic and discontinuous, interrupted by the stages of deep frost processes. Such interplay of features is well known for Quaternary Bt horizons and could be used for pedostratigraphic inferences (summarized by VAN VLIET-LANOË 2010)

Concerning possible chronological and paleoecological implications we should take into account that no paleosols or pedosediments clearly correspond to the Early Würmian interstadials. Thus, we could suppose that the pedogenesis of these warmer stages could contribute to the formation of the "Eemian" profile in Oberlaab. In several profiles of Europe the soils of these interstadials are characterized by dark humus accumulation and correspond to steppe environment (e.g. Mosbacher Humuszonen in Germany, Krutitsa soil in Russia, etc.). From such type of pedogenesis one would not expect contribution to the clay illuviation. However, this type of soil and landscape conditions seems to be not sole during the Early Würmian interstadials. Forest ecosystems have been also registered by various European paleoecological proxies (BIBUs et al. 2002). The warmer climate and reforestation could provide conditions for Luvisol pedogenesis, although interrupted by cold phases of the early glacial. Early Würmian Bt horizons clearly separated from the Eemian 
Luvisol and correlative to Mosbacher Humuszonen were reported in the Rhine Area (LESER 1970). As mentioned above (see 'Introduction') several authors described superimposing of the Early Würmian clay illuviation (associated with Grey Forest Soil formation) over the pre-existing Eemian Luvisol producing a pedocomplex.

We suppose that Early Würmian clay illuviation could develop in the "Eemian" Argic horizon interrupted by frost processes imposed by the cold stadials in Oberlaab. Thus, its morphological and analytical (clay content, geochemical differentiation) characteristics could be an integral of longer Luvisol pedogenesis including Eemian Interglacial sensu lato (MIS 5e and part of MIS 5d) and Early Würmian interstadials (correlative to MIS 5c and MIS 5a). Such cumulative effect could be present in a number of the Eemian Luvisol profiles where Early glacial sedimentation was not sufficient to separate interglacial and interstadial soil bodies. In this way we return to the earlier ideas of BOARDMAN (1985) who stated: "Geological and palynological evidence from terrestrial, midlatitude sites suggests that temperate conditions conducive to soil formation existed for periods greatly in excess of $10,000 \mathrm{yr}$ during the middle and late Pleistocene. Available data on soils formed during this interval from Western Europe and midwestern United States are best explained by relatively long interglaciations or the development of composite soils over a number of temperate periods".

\section{Acknowledgements}

We would like to thank all colleagues - scientists and students from Austria, Germany, Mexico and Russia who took part in the field and laboratory research of the ICSU 2003 project "Polygenetic models for Pleistocene paleosols" and generated a productive and friendly atmosphere of the project sessions. We are grateful to the International Council of Science (ICSU) whose funding made possible this wonderful experience of intensive interdisciplinary and international collaboration. Special thanks are for Prof. Winfried Blum who encouraged us at the initial stage of the ICSU Project development and provided valuable advices and support.

We would also like to express our gratitude to Dirección General de Asuntos de Personal Académico, UNAM (DGAPA UNAM) for funding the sabbatical stay of S. Sedov in the University of Würzburg, allowing to finalize this research and to prepare the results for publication.

\section{References}

Antoine, P., Rousseau, D.D., Lautridou, J.P. \& Hatté, C. (1999): Last Interglacial-Glacial climatic cycle in loess-palaeosol successions of north-western France. - Boreas, 28: 551-563.

Antoine. P., Rousseau, D., Zöller, L., Lang, A., Munaut, A.V., Hatté, C. $\mho$ Fontugne, M. (2001): High-resolution record of the last InterglacialGlacial cycle in the Nussloch loess-palaeosol sequences, Upper Rhine Area, Germany. - Quaternary International, 76 (77): 211-229.

BAMHISEL, R.I. \& BERTSCH P.M. (1989): Chlorites and hydroxy-interlayered vermiculite and smectite. - In: Dixon, J.B., \& WEED, S.B. (eds): Minerals in Soil Environments: 729-788; Madison, Wisconsin (Soil Science Society of America).

Bibus, E., Rahle, W. \& Wedel, J. (2002): Profilaufbau, Molluskenführung undParallelisierungsmöglichkeitdes AltwürmabschnittesimLössprofil Mainz-Weisenau. - Eiszeitalter und Gegenwart, 51: 1-14.

BoARdMAn, J. (1985): Comparison of soils in Midwestern United States and
Western Europe with the interglacial record. - Quaternary Research, 23: $62-75$.

BRINKMAN, R. (1970): Ferrolysis, a hydromorphic soil forming process. Geoderma, 3: 199-206.

BRONGER, A. (1976): Zur quartären Klima- und Landschaftsgeschichte des Karpatenbeckens auf paläopedologischer und bodengeographischer Grundlage. - Kieler Geographische Schriften, 45: 1-268.

Bronger, A. (2003): Bodengeographie der Waldsteppen und Steppen. In: Blume, H. P., Felix-Henningsen, P., Fischer, W. R., Frede, H. G. Horn, R. \& StaHr, K. (eds): Handbuch der Bodenkunde, 1-6; Landsberg/Lech (Ecomed).

Bronger, A. \& Heinkele, T. (1990): Mineralogical and clay mineralogical aspects of loess research. - Quaternary International, 7-8: 37-51.

Bronger, A., Winter, R. $\mho$ HeInkele, T. (1998): Pleistocene climatic history of East and Central Asia based on paleopedological indicators of loesspaleosol sequences. - Catena, 34: 1-17.

Bronnikova, M.A., SEdov, S.N. $\mho$ TARgulian, V.O. (2000): Clay, iron-clay, and humus-clay coatings in the eluvial part of Soddy-Podzolic soils profile. - Eurasian Soil Science, 33(6): 577-585.

Bullock, P., Fedoroff, N., Jongerius, A., Stoops, G., Tursina, T. ¿ Babel, U. (1985): Handbook for soil thin section description. - 152 p., Wolverhampton, United Kingdom (Waine Research Publications).

Bullock, P. \& ThOMPSON, M.L. (1985): Micromorphology of Alfisols.- In: Douglas, L.A. \& Thompson, M.L. (eds): Soil micromorphology and soil classification, Soil Science Society of America Special Publication, 15: 17-47; Madison.

Caspers, G., Freund, H., Merkt, H., Merkt, J. \& Müller, H. (2002): The Eemian interglaciation in northwestern Germany. - Quaternary Research, 58: 49-52.

CATT, J.A. (1996): Recent work on Quaternary paleosols in Britain. - Quaternary International, 3436: 183-190.

Deмeк, J. \& Kukla, J. (eds.) (1969): Periglazialzone, Löss und Paläolithicum der Tschechoslowakei. - 158 p., Brno (Tschechoslowakische Akademie der Wissenschaften, Geographisches Institut).

Fedorova, N.N. \& YARILOvA, E.A. (1972): Morphology and genesis of prolonged seasonally frozen soils of western Siberia. - Geoderma, 7: 1-13.

FINK, J. (1956): Zur Korrelation der Terrassen und Lösse in Österreich. - Eiszeitalter und Gegenwart, 7: 49-77.

Frechen, M., Zander, A., Cilek, V. \& LoŽEk, V. (1999): Loess chronology of the Last Interglacial/Glacial cycle in Bohemia and Moravia, Czech Republic. - Quaternary Science Reviews, 18: 1467-1493.

Gerasimenko, N.P. (2006): Upper Pleistocene loess-palaeosol and vegetational successions in the Middle Dnieper Area, Ukraine. - Quaternary International, 149: 55-66.

Gerasimova, M.I., Gubin, S.V. ¿ Shoba, S.A. (1996): Soils of Russia and adjacent countries: Geography and Micromorphology. - 204 p.; MoscowWageningen (Moscow State University \& Wageningen Agricultural University).

Golyeva, A. \& Sycheva, S. (2010): Soils, plants and climate of the Eemian Interglacial local landscapes of the Russian Plain on base of biogenic silica analysis. - Eurasian Soil Science, , 43, 13: 1569-1573.

Haeserts, P., Mestdagh, H. \& Bosquet, D. (1999): The sequence of Remicourt (Hesbaye, Belgium): new insights of the pedo- and chronostratigraphy of the Rocourt Soil. - Geologica Belgica, 2: 5-27.

Haeserts, P. \& Mestdagh, H. (2000): Pedosedimentary evolution of the last interglacial and early glacial sequence in the European loess belt from Belgium to central Russia. - Geologie en Mijnbouw / Netherlands Journal of Geosciences, 79 (2/3): 313-324.

Jamagne, M., De Coninck, F., Robet, M. $\mho$ Maucorps, J. (1984): Mineralogy of clay fractions of some soils on loess in northern France. - Geoderma, 33: 319-342.

JARY, Z. (2009): Periglacial markers within the Late Pleistocene loess-palaeosol sequences in Poland andwestern part of Ukraine. - Quaternary International, 198: 124-135.

JARY, Z. (ed.) (2011): Closing the gap - North Carpathian loess traverse in the Eurasian loess belt. - International Workshop, 6th Loess Seminar in Wrocław, May 16-21, 2011, Abstract and field guide book, 80 p.; Wrocław (Institute of Geography and Regional Development, University of Wrocław).

KEMP, R.A. (1999): Micromorphology of loess-palaeosol sequences: a record of palaeoenvironmental change. - Catena, 35(2-4): 179-196.

Kooistra, M.J. \& Pulleman, M.M. (2010): Features related to faunal activity. - In: Stoops, G., MARCELINo, V. \& MEEs, F. (eds): Interpretation of Micromorphological Features of Soils and Regoliths. Chapter 18: $397-$ 418; Amsterdam (Elsevier).

KüHN, P. (2003): Micromorphology and Late Glacial/Holocene genesis of 
Luvisols in Mecklenburg-Vorpommern (NE-Germany). - Catena, 54: 537-555.

Kühn, P., Billwitz, K., Bauriegel, A., Kühn, D. ひ EckelmanN, W. (2006) Distribution and Genesis of Fahlerden (Albeluvisols) in Germany. Journal of Plant Nutrition and Soil Science, 169: 420-433.

KüHn, P., Aguilar, J. \& Miedema, R. (2010): Textural pedofeatures and related horizons. - In: Stoops, G., MARcelino, V. \& MeEs, F. (eds): Interpretation of Micromorphological Features of Soils and Regoliths. Chapter 11: 217-250; Amsterdam (Elsevier).

Kukla, G.J. (1977): Pleistocene land-sea correlations I. Europe. - Earth-Science Reviews, 13(4): 307-374.

Kukla, G.J., Bender, M.L., De Beaulieu, J.L., Bond, G., Broecker, W.S., Cleveringa, P., Gavin, J.E., Herbert, T.D., Imbrie, J., Jouzel, J., Keigwin, L.D., Knudsen, K.L., McManus, J.F., Merkt, J., Muhs, D.R., Muller, H., Poore, R.Z., Porter, S.C., Seret, G., Shackleton, N.J., Turner, C., Tzedakis, P.C. \& Winograd, I.J. (2002): Last interglacial climates. - Quaternary Research, 58: 2-13.

Leser, H. (1970): Die fossilen Böden im Lößprofil Wallertheim (Rheinhessisches Tafel- und Hügelland). - Eiszeitalter und Gegenwart, 21: $108-121$.

Mahaney, W.C., Andres, W. \& Barendregt, R.W. (1993): Quaternary paleosol stratigraphy and paleomagnetic record near Dreihausen, central Germany. - Catena, 20(1-2): 161-177.

Markovic, S.B., Bokhorst, M.P., VANDEnberghe, J., McCoy, W.D., Oches, E.A., Hambach, U., Gaudenyi, T., Jovanovic, M., Zöller, L., Stevens, T. \& MAchaLETt, B. (2008): Late Pleistocene loess-paleosol sequences in the Vojvodina region, North Serbia. - Journal of Quaternary Science, 23(1): 73-84.

Miedema, R., Koulechova, I.N. ¿ GeRAsimova, M.I. (1999): Soil formation in Greyzems in Moscow district: micromorphology and particle size distribution. - Catena, 34(3-4): 315-347.

Morozova, T.D. (1981): Evolution of Late Pleistocene soil cover in Europe. - 282 p., Moscow (Nauka Press), in Russian.

Morozova, T.D., Velichko, A.A. \& Duussky, K.D. (1998): Organic carbon content in the late Pleistocene and Holocene fossil soils (reconstruction for Eastern Europe). - Global and Planetary Change, 16-17: 131-151.

MOORE, D.E. \& REYNOLDS, R.C.JR. (1997): X-Ray diffraction and the identification and analysis of clay minerals. - 378 p., New York (Oxford University Press).

PÉDRo, G., JamAgne, M. \& BÉGON, J.C. (1978): Two routes in genesis of strongly differentiated acid soils under humid, cool-temperate conditions. - Geoderma, 20: 173-189.

Peticzka, R., Riegler, D. ¿ Holawe, F. (2009): Exkursionsführer. - 28 Jahrestagung des Arbeitskreises Paläopedologie der Deutschen Bodenkundlichen Gesellschaft, 21. bis 23. Mai 2009 in Wien, 68 p.; Wien (Universität Wien, Institut für Geographie und Regionalforschung).

Rivas, J., Ortega, B., Sedov, S., Solleiro, E. \& Sycheva, S. (2006): Rock magnetism and pedogenetic processes in Luvisol profiles: Examples from Central Russia and Central Mexico. - Quaternary International, 156/157: 212-223.

Rousseau, D.D., Gerasimenko, N., Matvishina, Z.H. \& KukLa, G. (2001): Late Pleistocene environments of the Central Ukraine. - Quaternary Research, 56: 349-356.

Rutter, N.W., Rokosh, D., Evans, M.E., Little, E.C., Chlachula, J. \& Velichro, A. (2003): Correlation and interpretation of paleosols and loess across European Russia and Asia over the last interglacial-glacial cycle. - Quaternary Research, 60(1): 101-109.

Sauer D., Schülli-Maurer I., Sperstad R., Sørensen R. ש Stahr K. (2009): Albeluvisol development with time in loamy marine sediments of southern Norway. - Quaternary International, 209(1-2): 31-43.

SCHOLGER, R. \& TERHORST, B. (2013): Magnetic excursions recorded in the Middle to Upper Pleistocene loess/palaeosol sequence Wels-Aschet (Austria). - E \& G Quaternary Science Journal, 62/1, this volume.

SHACKLEton, N.J. (1969): The last interglacial in the marine and terrestrial records. - Proceedings of Royal Society London B, 174: 135-154.

Shackleton, N.J., SÁnchez-GoÑi, M.F., Pailler, D. \& Lancelot, Y. (2003): Marine isotope substage 5e and the Eemian interglacial. - Global and Planetary Change, 36: 151-155.

Sier, M.J., Roebroeks, W., Bakels, C.C., Dekkers, M.J., Brühl, E., De Loecker, D., Gaudzinski-Windheuser, S., Hesse, N., Jagisch, A., Kindler, L., KuijPer, W.J., Laurat, T., MÜcher, H.J., Penkman, K.E.H., Richter, D. ひ VAN HinsBergen, D.J.J. (2011): Direct Terrestrial-Marine Correlation demonstrates surprisingly late onset of the last interglacial. - Quaternary Research, 75: 213-218.

Solleiro-Rebolledo, E., Cabadas, H., Sedov, S. \& Terhorst, B. (2013): Paleopedological record along the loess-paleosol sequence in Oberlaab, Austria. - E \& G Quaternary Science Journal, 62/1, this volume.
Spiridonova, I.A., Sedov, S.N., Bronnikova, M.A. \& Targulian, V.O (1999): Arrangement, composition, and genesis ofbleached components of loamy Soddy-Podzolic soils. - Eurasian Soil Science, 32(5): 507-513. Sprafke, T., Terhorst, B., Peticzka, R. ¿ Thiel, C. (2013): Middle and Late Pleistocene paleoenvironments reconstructed from the complex loesspaleosol-sequence Paudorf. - E \& G Quaternary Science Journal, 62/1, this volume.

Stephan, S. (2000): Bt-Horizonte als Interglazial-Zeiger in den humiden Mittelbreiten:Bildung, Mikromorphologie, Kriterien. - Eiszeitalter und Gegenwart, 50: 95-106.

Sycheva, S.A. (1998): New data on composition and evolution of the Mezin Loess-Paleosol Complex in the Russian Plain. - Eurasian Soil Science, 31(10): 1062-1074.

Sycheva, S. \& Sedov, S. (2012): Paleopedogenesis during Mikulino interglacial (MIS 5e) in East-European plain: buried toposequence of the key-section "Alexandrov quarry". - Boletín de la Sociedad Geológica Mexicana, 64(2): 189-197.

Targulian, V.O., Birina, A.G., Kulikov, A.V., Sokolova, T.A. \& TselishCHEVA, L.K. (1974): Arrangement, composition and genesis of sod-palepodzolic soil derived from mantle loams. Morphological investigation - 10th International Congress in Soil Science, 47 p.; Moscow (Academy of Sciences of the USSR).

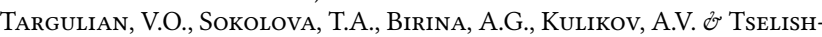
CHEVA, L.K. (1974): Arrangement, composition and genesis of sod-palepodzolic soil derived from mantle loams. Analytical investigation. 10th International Congres in Soil Science., 107 p.; Moscow (Academy of Sciences of the USSR).

Terhorst, B. (2007): Korrelation von mittelpleistozänen Löss-/Paläobodensequenzen in Oberösterreich mit der marinen Sauerstoffisotopenkurve. - E \& G Quaternary Science Journal, 56: 172-185.

Terhorst, B. (2013): A stratigraphic concept for Middle Pleistocene Quaternary sequences in Upper Austria. - E \& G Quaternary Science Journal, $62 / 1$, this volume.

Terhorst, B. , Appel, E. \& Werner, A. (2001): Palaeopedology and magnetic susceptibility of a loess-palaeosol sequence in southwest Germany. - Quaternary International, 76-77: 231-240.

Tonkonogov, V.D., Gradusov, B.P., Rubilina, N.Y.E., Targulian, V.O. ¿ Chizhiкova N.P. (1987): Differentiation of the mineral and chemical composition in sod-podzolic and podzolic soils. - Soviet Soil Science, 19(4): 23-35.

TuRNER, C. (2002a): Formal status and vegetational development of the Eemian interglacial in northwestern and southern Europe. - Quaternary Research, 58: 41-44.

Turner, C. (2002b): Problems of the duration of the Eemian interglacial in Europe North of the Alps. - Quaternary Research, 58: 45-48.

VAN VLIET-LanoË, B. (1990): The genesis and age of the argillic horizon in Weichselian loess of northwestern Europe. - Quaternary International, 5: 49-56.

van Vliet-LanoË, B. (2010): Frost action. - In: Stoops, G., Marcelino, V. \& MeEs, F. (eds): Interpretation of Micromorphological Features of Soils and Regoliths. Chapter 6: 81-10; Amsterdam (Elsevier).

van Ranst, E., DE Coninck, F., Tavernier, R. \& Langohr, R. (1982): Mineralogy in silty to loamy soils of central and high Belgium in respect of autochtonous and allochtonous materials. - Bulletin de la Societé belge de géologie, 91(1): 27-44.

Vancampenhout, K., Wouters, K., Caus, A., Buurman, P., Swennen, R. ש DECKERS, J. (2008): Fingerprinting of soil organic matter as a proxy for assessing climate and vegetation changes in last interglacial palaeosols (Veldwezelt, Belgium). - Quaternary Research, 69(1): 145-162.

Vandenhoute, P., Frechen, M., Buylaert, J.P., Vandenberghe, D. ש Decorte, F. (2003): The Last Interglacial palaeosol in the Belgian loess belt TL age record. - Quaternary Science Reviews, 22: 985-990.

Velichko, A.A. (1990): Loess-paleosol formation on the Russian Plain. Quaternary International, 7/8: 103-114.

Velichio, A.A., Morozova, T.D., Nechaev, V.P., Rutter, N.W., DlusskiI, K.G., Little, E.C., Catto, N.R., Semenov, V.V. \& Evans, M.E. (2006): Loess/paleosol/cryogenic formation and structure near the northern limit of loess deposition, East European Plain, Russia. - Quaternary International, 152 (1): 14-30

WoJDYR, M. (2010): Fityk: a general-purpose peak fitting program. - Journal of Applied Crystallography, 43: 1126-1128.

YAкIMENKO, E.Y.(1995): Pleistocene paleosols in the loess and loess-like sediments of the central part of the Russian Plain. - Quaternary Science Reviews, 14: 747-753.

Zagwijn, W.H. (1996): An analysis of Eemian climate in western and central Europe. - Quaternary Sciences Reviews, 15: 451-469. 